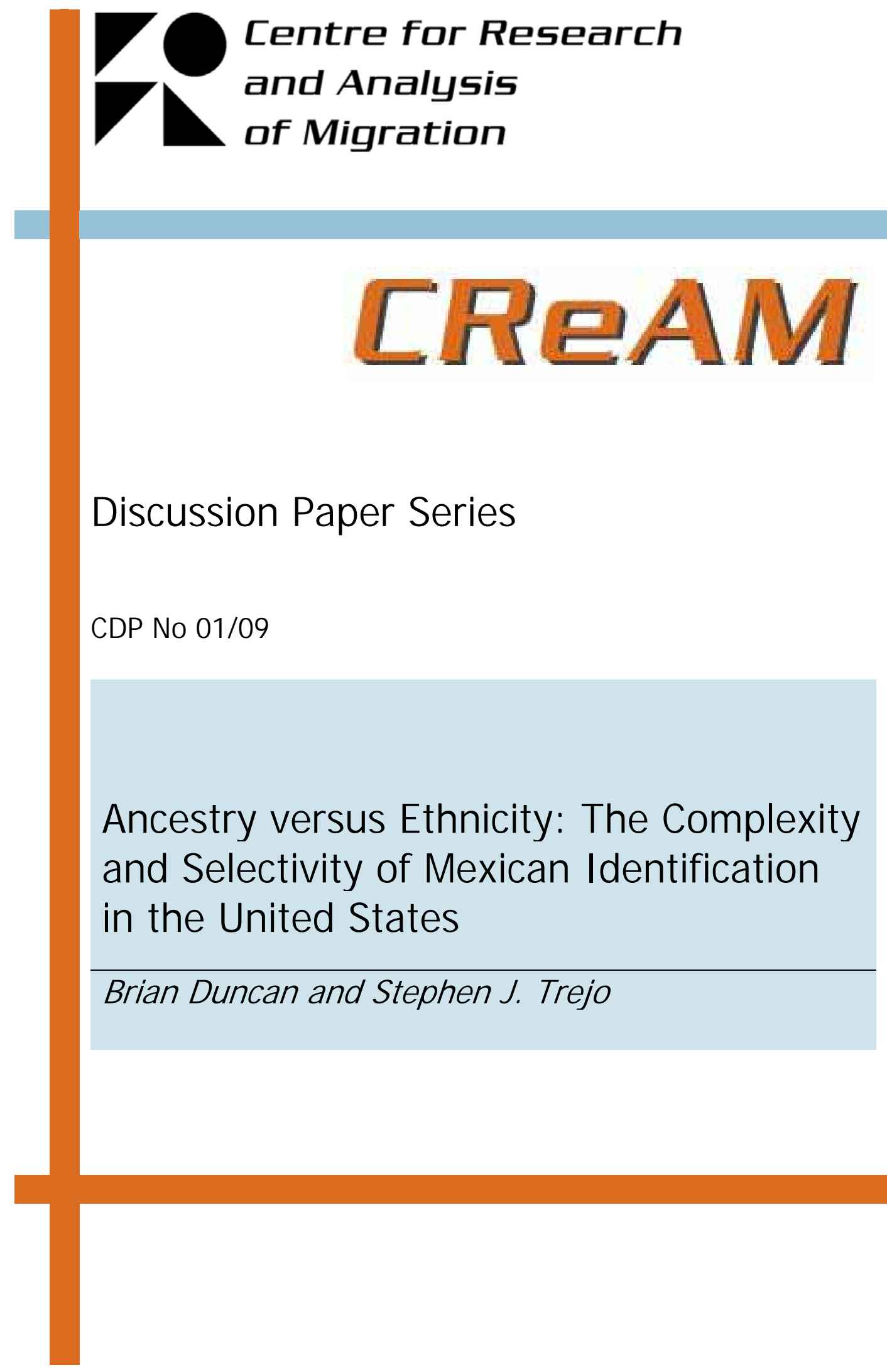




\title{
Ancestry versus Ethnicity: The Complexity and Selectivity of Mexican I dentification in the United States
}

\author{
Brian Duncant and Stephen J. Trejo* \\ † Department of Economics, University of Colorado at Denver \\ * Department of Economics, University of Texas at Austin
}

\begin{abstract}
Non-Technical Abstract
Using microdata from the 2000 U.S. Census, we analyze the responses of Mexican Americans to questions that independently elicit their "ethnicity" (or Hispanic origin) and their "ancestry." We investigate whether different patterns of responses to these questions reflect varying degrees of ethnic attachment. For example, those identified as "Mexican" in both the Hispanic origin and the ancestry questions might have stronger ethnic ties than those identified as Mexican only in the ancestry question. How U.S.-born Mexicans report their ethnicity/ancestry is strongly associated with measures of human capital and labor market performance. In particular, educational attainment, English proficiency, and earnings are especially high for men and women who claim a Mexican ancestry but report their ethnicity as "not Hispanic." Further, intermarriage and the Mexican identification of children are also strongly related to how U.S.-born Mexican adults report their ethnicity/ancestry, revealing a possible link between the intergenerational transmission of Mexican identification and economic status.
\end{abstract}




\title{
Ancestry versus Ethnicity: The Complexity and Selectivity of Mexican Identification in the United States
}

\author{
Brian Duncan \\ Department of Economics \\ University of Colorado at Denver \\ Campus Box 181 \\ Denver, CO 80217-3364 \\ (303) 556-6763 \\ bduncan@carbon.cudenver.edu \\ Stephen J. Trejo \\ Department of Economics \\ University of Texas at Austin \\ 1 University Station C3100 \\ Austin, TX 78712-0301 \\ (512) 475-8512 \\ trejo@eco.utexas.edu
}

May 2008

\begin{abstract}
Using microdata from the 2000 U.S. Census, we analyze the responses of Mexican Americans to questions that independently elicit their "ethnicity" (or Hispanic origin) and their "ancestry." We investigate whether different patterns of responses to these questions reflect varying degrees of ethnic attachment. For example, those identified as "Mexican" in both the Hispanic origin and the ancestry questions might have stronger ethnic ties than those identified as Mexican only in the ancestry question. How U.S.-born Mexicans report their ethnicity/ancestry is strongly associated with measures of human capital and labor market performance. In particular, educational attainment, English proficiency, and earnings are especially high for men and women who claim a Mexican ancestry but report their ethnicity as "not Hispanic." Further, intermarriage and the Mexican identification of children are also strongly related to how U.S.-born Mexican adults report their ethnicity/ancestry, revealing a possible link between the intergenerational transmission of Mexican identification and economic status.
\end{abstract}




\section{Introduction ${ }^{1}$}

The 2000 U.S. Census contains several questions that potentially indicate something about the respondent's racial/ethnic identity. In particular, information is collected on country of birth, language spoken at home, race, Hispanic origin, and ancestry. In this paper, we focus on these last two variables, and we explore how important indicators of human capital and labor market performance vary with the pattern of responses that U.S.-born Mexican Americans give to the Hispanic origin and ancestry questions. We also investigate how reported ethnicity/ancestry correlates with the extent and selectivity of Mexican intermarriage and with the Mexican identification of children.

Starting in 1980, the U.S. Census has included an open-ended question asking for each person's "ancestry or ethnic origin,” and the first two responses are coded in the order that they are reported. This ancestry information is in addition to the race and Hispanic origin questions typically employed to identify racial/ethnic groups. The Hispanic origin and ancestry questions give Mexican Americans multiple ways of expressing ethnic identification in Census data. We consider whether for Mexicans it makes sense to think of different patterns of responses to these questions as indicating varying degrees of ethnic attachment. For example, perhaps those identified as "Mexican" in both the Hispanic origin and the ancestry questions tend to have stronger levels of ethnic attachment than those identified as Mexican only in the ancestry question. In particular, individuals who identify as "not Hispanic” in response to the Hispanic origin question but nonetheless list Mexican as an ancestry may represent a segment of the

\footnotetext{
${ }^{1}$ For helpful comments, we are grateful to Lauren Krivo and two anonymous reviewers. This research was supported by NICHD grants 5R03HD050574-02 to Stephen Trejo and 5R24HD042849 to the Population Research Center at the University of Texas at Austin.
} 
Mexican-American population with weaker or more distant ethnic ties. ${ }^{2}$ If so, then differences in human capital and labor market outcomes between such groups might provide clues as to the nature of the selectivity for those individuals of Mexican descent whose ethnicity is obscured because in neither the Hispanic origin nor the ancestry questions do they disclose their Mexican origins.

The current paper is part of our larger research program that, using various approaches, has uncovered evidence of selective ethnic attrition among Mexican Americans. In Duncan and Trejo (2007), we show that intermarriage to non-Mexicans is widespread among U.S.-born Mexican Americans, and also that Mexican Americans who intermarry are substantially more educated and English proficient, on average, than are Mexican Americans who marry co-ethnics (whether they be U.S.-born Mexicans or Mexican immigrants). Furthermore, Mexican intermarriage exerts a strong influence on reported ethnicity for children of Mexican descent. Not surprisingly, virtually all children with two Mexican-origin parents are identified as Mexican in Census data, but about 30 percent of the children of intermarried Mexican Americans are not identified as Mexican. As this dynamic plays out across generations, an increasingly small fraction of the descendants of Mexican immigrants continue to identify themselves as Mexican. Moreover, the human capital selectivity of Mexican intermarriage implies that this ethnic leakage is also selective. As a result, available data for third- and highergeneration Mexicans_-the grandchildren and later descendants of Mexican immigrants, who usually can only be identified from their subjective responses to questions about Hispanic ethnicity — understate the socioeconomic attainment of this population. In effect, through the

\footnotetext{
${ }^{2}$ This segment of the Mexican-American population-representing persons of Mexican ancestry who answer "not Hispanic" to the Hispanic origin question—is of special importance, because it is missed by virtually all studies of U.S.-born Hispanics or Mexicans.
} 
selective nature of intermarriage and ethnic identification, some of the most successful descendants of Mexican immigrants assimilate to such an extent that they fade from empirical observation.

In Duncan and Trejo (2008), we confirm explicitly the critical role that intermarriage plays in the parent-child transmission of human capital and ethnic identification for Mexican Americans. Exploiting data from the Current Population Survey, we also directly assess the extent and selectivity of ethnic attrition by comparing an "objective” indicator of Mexican descent (based on the countries of birth of the respondent and his parents and grandparents) with the standard "subjective" measure of Mexican self-identification (based on the respondent's answer to the Hispanic origin question). For second-generation Mexican-American adults, we find direct evidence of the kind of selective ethnic attrition that our previous work (Duncan and Trejo 2007) could only suggest indirectly. For third-generation Mexican-American youth, we show that ethnic attrition is substantial and could produce significant downward bias in standard measures of attainment which rely on ethnic self-identification rather than objective indicators of Mexican ancestry.

This line of research acquires special significance from widespread concern that, for a variety of reasons, the descendants of Mexican immigrants may not experience the same kind of intergenerational advancement that allowed previous groups of unskilled immigrants, such as the Italians and Irish, to eventually enter the economic mainstream of American society (Gans 1992; Portes and Zhou 1993; Rumbaut 1994; Portes and Rumbaut 2001; Huntington 2004; Perlmann 2005). Legitimizing such concern, many empirical analyses indicate that the economic disadvantage of Mexican Americans persists even among those whose families have lived in the United States for more than two generations, and that the substantial progress observed between 
the first and second generations seems to stall thereafter (Trejo 1997, 2003; Fry and Lowell 2002; Farley and Alba 2002; Grogger and Trejo 2002; Livingston and Kahn 2002; Duncan, Hotz, and Trejo 2006; Blau and Kahn 2007). ${ }^{3}$ The possibility of selective ethnic attrition, however, calls into question findings from studies such as these that compare education and earnings across generations of Mexican Americans.

For other groups, selective ethnic identification has been shown to distort observed socioeconomic characteristics. American Indians are an especially apt example, because they exhibit very high rates of intermarriage, and fewer than half of the children of such intermarriages are identified as American Indian by the Census race question (Eschbach 1995). For these and other reasons, racial identification is relatively fluid for American Indians, and changes in self-identification account for much of the surprisingly large increase in educational attainment observed for American Indians between the 1970 and 1980 U.S. Censuses (Eschbach, Supple, and Snipp 1998). Of particular relevance for our study, Snipp (1989) shows that those who report American Indian as their race have considerably lower schooling and earnings, on average, than the much larger group of Americans who report a non-Indian race but claim to have some Indian ancestry.

A few studies have examined responses to the Census ancestry and Hispanic origin questions along the lines that we do here. For Hispanics in general (rather than Mexicans in particular), Emeka (2008) notes that the 2006 American Community Survey includes a relatively

\footnotetext{
${ }^{3}$ As noted by Borjas (1993) and Smith (2003), generational comparisons in a single cross-section of data do a poor job of matching immigrant parents and grandparents in the first generation with their actual descendants in later generations. Indeed, Smith (2003) finds evidence of more substantial gains between second- and third-generation Mexicans when he combines crosssectional data sets from successive time periods in order to compare second-generation Mexicans in some initial period with their third-generation descendants twenty-five years later. Yet even Smith's analysis shows signs of intergenerational stagnation for Mexican Americans. In his Table 4, for example, five of the six most recent cohorts of Mexicans experience no wage gains between the second and third generations. Moreover, all studies conclude that large education and earnings deficits (relative to non-Hispanic whites) remain for third- and higher-generation Mexicans. Borjas (1994) and Card, DiNardo, and Estes (2000) investigate patterns of intergenerational progress for many different national origin groups, including Mexicans.
} 
small but non-negligible number of individuals who list an Hispanic ancestry but simultaneously identify themselves as "not Hispanic" in response to the Hispanic origin question. Dubbing this group the “Hispanic non-Hispanics,” Emeka shows that they have significantly higher family incomes, on average, than their counterparts who consistently identify as Hispanic in response to both the ancestry and the Hispanic origin questions. Using 2000 Census data and focusing on Mexicans, as we do here, Ghazal Read (2005) and Alba and Islam (2008) demonstrate that individuals who list a Mexican ancestry but identify as "not Hispanic” in response to the Hispanic origin question possess higher levels of educational attainment and English proficiency than do those individuals who consistently identify as Mexican. Unlike these other studies, however, we provide a detailed analysis of how the complexity of Mexican identification relates to key indicators of human capital and labor market success, and we also explore the links between reported ethnicity/ancestry, intermarriage, and the Mexican identification of children.

In recent Censuses, a growing fraction of U.S. Hispanics have responded to the Hispanic origin question with a pan-ethnic label (such as “Latino” or "Hispanic”) rather than by designating a specific national origin group (such as "Mexican” or “Cuban”). ${ }^{4}$ Many such individuals are Mexican-origin, as indicated by their reported ancestry and/or country of birth. Our analysis sheds light on the socioeconomic characteristics of this group and how its exclusion from most empirical research on the Mexican-American population may influence findings. More generally, our paper contributes to the burgeoning academic literature on the complexity and fluidity of ethnic identification. Until quite recently, empirical research on this topic for the United States has focused primarily on whites of European descent (Alba and Chamlin 1983; Lieberson and Waters 1988; 1993; Alba 1990; Waters 1990; Farley 1991), and

\footnotetext{
${ }^{4}$ See Logan (2002) and Cresce and Ramirez (2003).
} 
therefore new insights could be gained from an analysis such as ours that highlights ethnic choices among the Mexican-origin population. Existing studies (Stephan and Stephan 1989; Eschbach and Gomez 1998; Ono 2002; Brown, Hitlin, and Elder 2006; Choi, Sakamoto, and Powers 2008; Perez 2008) demonstrate that the process of ethnic identification by Hispanics is fluid, situational, and at least partly voluntary, just as has been observed for non-Hispanic whites and other groups. Most of this work, however, analyzes Hispanics as an aggregate group, even though available evidence suggests that the ethnic responses of Mexican Americans may differ in fundamental ways from those of other Hispanics (Eschbach and Gomez 1998; Portes and Rumbaut 2001, Perez 2008). In addition, earlier studies do not directly address the issue that we highlight: the selective nature of Mexican identification and how it may distort our inferences about intergenerational progress for this population.

Although most research in this area has been conducted by social scientists outside of economics, our paper also contributes to an emerging literature within economics that explicitly recognizes the complexity of ethnic identification and has begun to investigate the implications of this complexity for labor market outcomes and policy. ${ }^{5}$ In particular, economic models emphasize the potential endogeneity of identity and suggest mechanisms through which ethnic identification could be associated with both observed and unobserved characteristics of individuals. To date, however, most empirical work in the relevant economics literature has focused on immigrants. The analysis presented here demonstrates that some of the same issues can apply to native-born members of minority groups. In addition, we emphasize the complications that intergenerational shifts in ethnic identify can create for measuring the

\footnotetext{
${ }^{5}$ Examples include Akerlof and Kranton (2000); Bisin and Verdier (2000); Darity, Hamilton, and Dietrich (2002); Bisin, Topa, and Verdier (2004); Mason (2004); Darity, Mason, and Stewart (2006); Constant, Gataullina, and Zimmermann (2006); Bodenhorn and Ruebeck (2007); Manning and Roy (2007); and Nekby and Rodin (2007). Constant and Zimmermann (2007) and Zimmermann (2007) survey some of the relevant literature.
} 
socioeconomic progress of later-generation descendants of immigrants.

\section{Census Data on Mexican Ethnicity and Ancestry}

Our empirical analysis uses the five-percent microdata sample from the 2000 U.S. Census, which provides information on both Hispanic origin and ancestry, as well as a wide range of socioeconomic characteristics. For our purposes, two important advantages of Census data are the huge sample sizes and the ability to merge information across family members residing in the same household.

Our initial samples include adult men and women ages 25-59. We focus on individuals in this age range because they are old enough that virtually all of them will have completed their schooling, yet they are young enough that observed labor market outcomes reflect their prime working years. Given our interest in ethnic identification, we exclude anyone whose information about Hispanic origin was imputed by the U.S. Census Bureau. Separate analyses are conducted for men and women.

Figure 1 displays the 2000 Census questions regarding Hispanic origin and ancestry that are central to our analysis. With respect to Hispanic origin, the Census first inquires whether the respondent is "Spanish/Hispanic/Latino.” If so, the respondent is asked to designate one specific Hispanic national origin group, with separate boxes that can be checked for Mexican (or Mexican American or Chicano), Puerto Rican, Cuban, and a final box that provides the opportunity to write in some other response (e.g., Nicaraguan or Ecuadorian). These write-in responses ultimately were classified and coded in some detail by the Census Bureau.

The Hispanic origin question appears near the front of the 2000 Census form, preceded only by questions asking for the respondent's name, telephone number, sex, and age. 
Immediately following the Hispanic origin question, the Census asks respondents to designate their "race,” which the U.S. government considers to be distinct from Hispanic origin. Indeed, Hispanics may be of any race, and Hispanic responses are not included among those that the Census race question prompts for. ${ }^{6}$ Two important changes initiated with the 2000 Census were placing the Hispanic origin item before the race item on the questionnaire, and allowing respondents to designate more than one race (Grieco and Cassidy 2001; del Pinal 2004). The Hispanic origin question, however, still requires a single response.

Later in the questionnaire, after collecting information about marital status, school attendance, and educational attainment, the 2000 Census has an open-ended question asking for the respondent's “ancestry or ethnic origin,” with space provided to write in as many as two responses (Lieberson and Waters 1988; Farley 1991). These responses were classified and coded in the order that they were written.

The Hispanic origin and ancestry questions give Mexican Americans multiple ways of expressing ethnic identification in Census data. For ease of exposition, throughout this paper we will use the term "ethnicity” to refer to an individual's response to the Census question regarding Hispanic origin, and we will use the term “ancestry" to refer to an individual's responses to the Census ancestry question. Employing this terminology, Table 1 summarizes the reported ethnicity and ancestry of the Mexican-American men and women in our samples. The first two columns pertain to Mexican immigrants (i.e., individuals who were born in Mexico), whereas the last two columns pertain to U.S.-born individuals who show any indication that they are of Mexican descent (i.e., persons who identify as Mexican in response to either the Hispanic origin question or the ancestry question, or in response to both questions). For Mexican immigrants,

\footnotetext{
${ }^{6}$ The Census race question has boxes that can be checked for white, black (or African American or Negro), American
} 
the sample sizes are 152,103 men and 121,955 women. For U.S.-born Mexicans, the sample sizes are 88,989 men and 92,644 women.

Perhaps not surprisingly, the top section of Table 1 shows that Mexican immigrants overwhelmingly respond to the Hispanic origin question that their ethnicity is Mexican, with observed rates around 93 percent for both men and women. Most of the remaining Mexican immigrants (representing 5 percent of men and 6 percent of women) respond with a pan-ethnic or “general Hispanic” label such as “Hispanic,” "Latino,” or “Spanish.”7 Very few Mexicanborn individuals report that they are either "not Hispanic” or that they belong to a specific Hispanic national origin group other than Mexican (e.g., Cuban or Salvadoran).

The distribution of reported ethnicity for U.S.-born Mexicans is similar to that for Mexican immigrants, but not quite as concentrated. Among U.S.-born individuals whose Mexican origins can be identified in Census data, about 88 percent report a Mexican ethnicity in response to the Hispanic origin question. Another 8-9 percent of such individuals give a “general Hispanic” response to the Hispanic origin question (with women somewhat more likely than men to respond in this way), and 3 percent report that they are "not Hispanic." In order to be included in our sample of U.S.-born Mexicans, the individuals in these last two groups must have listed Mexican as an ancestry.

In a similar manner, the middle section of Table 1 summarizes the responses of Mexican immigrants and U.S.-born Mexicans to the Census ancestry question. In contrast to the Hispanic origin question, which allows for only one reported ethnicity, the ancestry question records as

Indian or Alaska Native, various Asian national origin groups (e.g., Chinese, Filipino, or Korean), and “Some Other Race.”

${ }^{7}$ The "general Hispanic" ethnicity category also includes individuals who, in response to the Hispanic origin question, check the box for “other Spanish/Hispanic/Latino” (i.e., besides Mexican, Puerto Rican, or Cuban) but do not write anything in the space provided to designate a specific group. Logan (2002) and Cresce and Ramirez (2003) document and discuss the sharp increase in "general Hispanic" responses to the Hispanic origin question that occurred between the 1990 and 2000 U.S. Censuses. 
many as two responses. So as to produce ancestry categories that are mutually exclusive and exhaustive, we define these categories in a sequential fashion. The first ancestry category of “Mexican” includes anyone who gives this answer (or something equivalent, such as Mexican American or Chicano) in either of their two possible ancestry responses. Among the remaining individuals who do not report a Mexican ancestry, the second ancestry category of "general Hispanic” is assigned to anyone who lists a pan-ethnic Hispanic label in either of their two possible ancestry responses. ${ }^{8}$ The third ancestry category of "other ancestry" includes individuals who list one or two valid ancestries, but none of these reported ancestries fit within the "Mexican" or "general Hispanic" categories. Finally, individuals who do not respond to the ancestry question are assigned to the ancestry category of "not reported."

About 85 percent of Mexican immigrants and 80 percent of U.S.-born Mexicans list Mexican as an ancestry. However, sizeable numbers of Mexican Americans instead report a "general Hispanic" ancestry, with proportions of 5 percent for those born in Mexico and 8-9 percent for those born in the United States (as we observed for ethnicity, women are more likely than men to list a "general Hispanic" ancestry, particularly among the U.S.-born). Many people do not respond to the Census ancestry question, and in our samples this rate is especially high (approaching 10 percent) for U.S.-born men. Given that the ancestry question follows the Hispanic origin and race questions, some individuals who were able to describe their ethnicity in response to these earlier questions may have thought it redundant and unnecessary to answer the ancestry question.

In the bottom section of Table 1, we categorize individuals based upon their joint responses to the Hispanic origin and ancestry questions. These tabulations highlight the

\footnotetext{
${ }^{8}$ Specifically, the "general Hispanic” ancestry category includes individuals who give any of the following ancestry
} 
complexity of ethnic identification for Mexican Americans, particularly for those born in the United States. In our samples of U.S.-born men and women who give some indication that they are of Mexican descent, just over two-thirds of these individuals answer "Mexican" to both the Hispanic origin and the ancestry questions in the Census. About 20 percent report a Mexican ethnicity but do not list a Mexican ancestry, and the remaining 11-12 percent identify as Mexican in response to the ancestry question but not the Hispanic origin question.

For our purposes, this last group is of special interest. Because most studies of U.S.-born Mexican Americans identify the target population using only the Hispanic origin question (or something very similar to it), the Mexican-origin samples in these studies typically exclude individuals who report a Mexican ancestry but not a Mexican ethnicity. Table 1 shows that most of these excluded Mexicans give a "general Hispanic" response to the Hispanic origin question, but among U.S.-born individuals many excluded Mexicans report their ethnicity as "not Hispanic." " U.S.-born adults who identify as "not Hispanic" (in response to the Hispanic origin question that appears near the front of the Census questionnaire) but nonetheless list Mexican as an ancestry (in response to the ancestry question that comes later) may represent a segment of the Mexican-American population with somewhat weaker or more distant ethnic ties. If so, then by studying this segment of the population we might be able to learn something about the selectivity of ethnic identification for Mexican Americans and about the potential for selective ethnic attrition to bias standard measures of socioeconomic status for the U.S.-born descendants of Mexican immigrants.

responses: Hispanic, Spanish, Spanish American, Latin American, Latino/Latina, and Latin.

${ }^{9}$ Instead of separately identifying Mexicans and other specific national origin groups, some studies of U.S. Hispanics analyze a single, aggregate group consisting of all individuals who indicate any type of Hispanic ethnicity. Such studies typically include as Hispanics people who give a "general Hispanic" response to the Hispanic origin question, but these studies almost always overlook persons of Mexican ancestry who identify as "not Hispanic” in the Hispanic origin question. 
The bottom section of Table 1 suggests that issues of ethnic identification are more clearcut for Mexican immigrants than for U.S.-born Mexicans. Over 80 percent of Mexican immigrants report Mexican as both their ethnicity and their ancestry, and few Mexican immigrants list a Mexican ancestry while simultaneously responding "not Hispanic" to the Hispanic origin question. For the remainder of the paper, we will focus on U.S.-born persons of Mexican descent. Ethnic identity is likely to be much more fluid and malleable for U.S.-born individuals than for Mexican immigrants whose birthplace serves to reinforce their Mexican ethnicity. Indeed, our previous work (Duncan and Trejo 2008) shows that the issue of ethnic attrition matters most for Mexican-origin persons whose families have been in the United States for more than two generations.

\section{Mexican Ethnicity/Ancestry and Labor Market Success}

Do important socioeconomic characteristics of U.S.-born Mexicans vary across the Mexican ethnicity/ancestry groups introduced in the previous section? If not, then it may be unnecessary to move beyond standard empirical characterizations of Mexican identity that lump all Mexican Americans into a single group. Moreover, substantial homogeneity across Mexican ethnicity/ancestry groups would limit the magnitude of potential measurement biases arising from selective ethnic attrition.

We begin to answer this question in Table 2, which shows how several key outcomes vary by Mexican ethnicity/ancestry. ${ }^{10}$ The samples include U.S.-born men and women ages 25-

\footnotetext{
${ }^{10}$ We want to emphasize that our goal in this paper is not to estimate the causal effects of ethnic identification on Mexican-American outcomes. Instead, we seek only to describe the associations between Mexican ethnicity/ancestry responses and important socioeconomic phenomenon, in order to better understand the selectivity of ethnic identification among Mexican Americans and its potential implications for measuring their intergenerational progress. We do not attempt, however, to isolate the ultimate sources of this selectivity or to identify causal mechanisms.
} 
59 who report Mexican as an ethnicity and/or ancestry. The table reports averages (with standard errors in parentheses) of the following measures of human capital and labor market performance: completed years of schooling, ${ }^{11}$ percent deficient in English, percent employed, and the natural logarithm of average hourly earnings. We define someone to be "deficient" in English if they speak a language other than English at home and they report speaking English worse than "very well."12 The employment and earnings measures pertain to the calendar year preceding the Census. We compute average hourly earnings as the ratio of annual earnings to annual hours of work, where annual earnings are the sum of wage and salary income and selfemployment income, and annual hours of work are the product of weeks worked and usual weekly hours of work. The samples for the earnings data are limited to those who were employed. ${ }^{13}$ The sample sizes are 88,989 men and 92,644 women for the full samples, and 76,108 men and 69,043 women for the earnings samples.

Table 2 classifies U.S.-born Mexicans using the ethnicity/ancestry groups displayed in the bottom section of Table 1, with one small change. Table 1 shows that very few people simultaneously report a Mexican ancestry and an "other Hispanic” ethnicity, so in Table 2 (and throughout the remainder of the paper) these individuals are grouped together with the much larger number of individuals who report a Mexican ancestry and a "general Hispanic" ethnicity. Keep in mind, however, that given the relative sizes of its component groups, the combined category representing persons with Mexican ancestry and an ethnicity of "general or other

\footnotetext{
${ }^{11}$ Beginning in 1990, the Census questions about educational attainment were changed to ask specifically about postsecondary degrees obtained rather than years of schooling. We follow Jaeger's (1997) recommendations for how to construct a completed years of schooling variable from the revised education questions.

12 The Census asks individuals whether they "speak a language other than English at home," and those who answer affirmatively then are asked how well they speak English, with possible responses of "very well," "well,” "not well,” or "not at all." excluded.

${ }^{13}$ In addition, observations with computed hourly earnings below $\$ 2.50$ or above $\$ 500$ are considered outliers and
} 
Hispanic" is dominated by individuals who report a "general Hispanic" ethnicity. Also, because our samples of U.S.-born Mexicans are restricted to individuals who report a Mexican ethnicity and/or a Mexican ancestry, the Table 1 category labeled "neither ethnicity nor ancestry is Mexican” becomes irrelevant in Table 2.

Among persons who report a Mexican ethnicity, the group that stands out is people who do not respond to the Census ancestry question. For both men and women, those who do not report an ancestry have much lower levels of human capital and far worse labor market outcomes than any other group of Mexican Americans. Men with unreported ancestry, for example, average only 10.7 years of schooling, compared to 12.3 years for the majority group of U.S.-born Mexicans who report Mexican as both their ethnicity and their ancestry. ${ }^{14}$ Similarly, compared to the majority group, Mexican men with unreported ancestry have a higher rate of English deficiency (by 3 percentage points), a lower employment rate (by 19 percentage points), and a wage disadvantage (of about 16 percent). ${ }^{15}$ Putting aside the group with unreported ancestry, differences between other groups of men who report a Mexican ethnicity are generally small, except that those with "general Hispanic” or "other” ancestries tend to speak English better than those with a Mexican ancestry. The corresponding patterns for women are similar (see the bottom half of Table 2).

Among persons who list a Mexican ancestry but do not report a Mexican ethnicity, there are two quite distinct groups. Those who report a "general Hispanic” ethnicity have somewhat

\footnotetext{
${ }^{14}$ Farley (1991) shows that, in a broad sample of 1980 Census respondents which includes all nativity and racial/ethnic groups, persons with higher educational attainment are much more likely to respond to the ancestry question, and they are also much more likely to list multiple ancestries.

${ }^{15}$ For expositional convenience, throughout the paper we will treat log wage differences as representing percentage wage differentials, although we recognize that this approximation becomes increasingly inaccurate for log differences on the order of .25 or more in absolute value. In such instances, one can calculate the implied percentage wage differential as $e^{x}-1$, where $x$ represents the estimated log wage difference.
} 
lower levels of educational attainment, English proficiency, and earnings than are observed in the overall samples of U.S.-born Mexican men and women. In contrast, persons who list a Mexican ancestry but simultaneously report their ethnicity as "not Hispanic" have much higher levels of human capital and earnings than any other ethnicity/ancestry group of U.S.-born Mexicans. Compared to men who report Mexican as both their ethnicity and their ancestry, for example, men of Mexican ancestry who identify their ethnicity as "not Hispanic" enjoy a schooling advantage of over half a year, a rate of English deficiency that is 9 percentage points lower, and an hourly wage that is 10 percent higher. The patterns are very similar for women.

Note that the two ethnicity/ancestry groups considered in the preceding paragraph represent segments of the Mexican-American population that usually are excluded from empirical research on this population, because most studies use only the Hispanic origin question to identify U.S.-born persons of Mexican descent. As noted by Alba and Islam (2008), the very different characteristics of these two groups make it important to distinguish between them whenever possible. Persons of Mexican ancestry who identify their ethnicity as "not Hispanic" possess relatively high levels of human capital and earnings. This group seems to provide a prime example of ethnic attrition in which the attrition is "positively" selected, similar to what we found in our previous analyses of intermarriage and ethnic identification by Mexican Americans (Duncan and Trejo 2007, 2008). Persons of Mexican ancestry who report a "general Hispanic" ethnicity, on the other hand, possess relatively low levels of human capital and earnings, suggesting "negative" selection for the segment of the Mexican-origin population that adopts pan-ethnic Hispanic labels. Much of the selectivity of these two contrasting groups would be hidden if they were combined into a single category consisting of all persons who report a Mexican ancestry but not a Mexican ethnicity. 
The answers that Mexican Americans give to the Census questions regarding Hispanic origin and ancestry are associated with characteristics such as age and geographic location. For example, among U.S.-born Mexicans, older persons and those living in California are especially likely to report Mexican as both their ethnicity and their ancestry, whereas Texas residents and those living outside of a metropolitan area disproportionately list a Mexican ancestry along with a "general or other Hispanic" ethnicity. Hourly wages tend to be higher for older, more experienced workers and also in locations with an elevated cost of living (e.g., California and large metropolitan areas). Consequently, the substantial earnings advantage observed in Table 2 for persons of Mexican ancestry who likewise identify their ethnicity as Mexican compared to those who report a "general or other Hispanic" ethnicity may simply reflect, at least in part, age and locational differences between these two groups. More generally, to what extent are the patterns in Table 2—namely, the variation across Mexican ethnicity/ancestry groups in measures of human capital and labor market performance-driven by intergroup differences in age and location?

The least squares regression coefficients reported in Table 3 address this question. The dependent variables are the four outcomes introduced in Table 2, and the samples are the same as in Table 2. ${ }^{16}$ The key independent variables are dummies indicating each person's ethnicity/ancestry, with the reference group consisting of individuals who report Mexican as both their ethnicity and their ancestry. All regressions control for geographic location and age. The controls for geographic location are dummy variables identifying the nine Census divisions,

\footnotetext{
${ }^{16}$ Although the dependent variables indicating “Deficient English” and "Employment” are dichotomous, we choose to report least squares estimates (i.e., linear probability models) because the coefficients are easier to interpret, but probit estimates imply similar marginal effects. In order to account for the heteroskedasticity that arises with linear probability models (or for other reasons), Table 6 reports robust standard errors (White 1980) in parentheses for all regression specifications (including those without dichotomous dependent variables).
} 
the individual states of California and Texas, and whether the respondent resides in a metropolitan area. The controls for age are dummy variables identifying five-year age intervals. For the employment and earnings regressions, there is a second specification-the columns labeled (2) — that also conditions on the human capital variables that measure educational attainment and English proficiency.

Table 3 indicates that controlling for geographic location and age does not greatly change the general pattern of differences across ethnicity/ancestry groups shown previously in Table 2. Indeed, the regression-adjusted differences in schooling, English proficiency, and employment in Table 3 are very similar to the corresponding unadjusted differences implicit in Table 2. Conditioning on geographic location and age does attenuate some of the hourly earnings differences across ethnicity/ancestry groups, but even the regression-adjusted earnings differences remain economically and statistically significant. For example, compared to the reference group that reports Mexican as both their ethnicity and their ancestry, the wage disadvantage of men who report their ethnicity as "general or other Hispanic" shrinks from 8 percent (in Table 2) to 4 percent (in specification (1) of Table 3), but changes in other wage differentials are much more modest. The regression-adjusted differences in Table 3 continue to show that human capital and earnings are highest for U.S.-born Mexicans who identify their ethnicity as "not Hispanic” and lowest for those who do not report an ancestry. Compared to the majority group that lists Mexican as both their ethnicity and their ancestry, persons who report a “general Hispanic” ethnicity or ancestry also possess relatively low education and earnings.

The second specification of the employment and hourly earnings regressions conditions on observable human capital as well as geographic location and age. In particular, we add controls for years of schooling and English proficiency. Both measures of human capital have 
important impacts, in the expected directions, on the employment rates and wages of MexicanAmerican men and women. Employment and earnings increase with educational attainment and are lower for those who report less than the highest level of ability to speak English. The estimated effects of schooling and English proficiency on employment are somewhat larger for women than for men. The earnings regressions also show a higher return to education for women, but the impact of English ability on earnings is larger for men.

Comparing specifications (1) and (2) of the employment and earnings regressions in Table 3 reveals how much of the wage differences across Mexican ethnicity/ancestry groups can be explained by the corresponding differences in schooling and English proficiency. In general, the wage differentials associated with ethnicity/ancestry diminish but do not disappear in specification (2), which suggests that human capital differences account for part but not all of the earnings differences. An exception is that, for women, controlling for human capital completely eliminates the large wage disadvantage of Mexicans with unreported ancestry relative to the majority groups that lists both their ethnicity and their ancestry as Mexican. For men, human capital differences account for roughly two-thirds of the analogous wage gap.

\section{Mexican Intermarriage}

Intermarriage has always been a fundamental source of ethnic flux and leakage in American society (Lieberson and Waters 1988, Hout and Goldstein 1994, Perlmann and Waters 2007). For Mexican Americans, Rosenfeld (2002, Table 1) shows that intermarriage increased substantially between 1970 and 1980 and even more sharply between 1980 and 1990 . As of 2000, more than a third of married, U.S.-born Mexicans have non-Mexican spouses (Duncan and Trejo 2007). Because it takes two Mexican-origin spouses to create an endogamous Mexican 
marriage, whereas a Mexican intermarriage requires only one Mexican-origin spouse, the observed rate of intermarriage implies that almost half of Mexican-American marriages involve a non-Mexican spouse. Indeed, Perlmann and Waters (2004) argue that the proclivity for intermarriage by second-generation Mexicans today is similar to what was observed for secondgeneration Italians in the early 1900s. This argument has potentially provocative implications for ethnic attachment among future generations of Mexican Americans, because intermarriage became so commonplace for subsequent generations of Italian Americans that Alba (1986) characterized this group as entering the "twilight of ethnicity."

Because intermarriage is probably the predominant source of leakage from the population of self-identified Mexican Americans (through the ethnic choices made by the children and grandchildren of these intermarriages), knowing the extent and selectivity of Mexican intermarriage is important for evaluating the potential bias that such leakage could produce in intergenerational comparisons (Duncan and Trejo 2007, 2008). More generally, intermarriage is of interest because it is often viewed as the ultimate indicator of assimilation by an ethnic group with immigrant origins (Gordon 1964, Alba and Nee 2003), and also because it is a key determinant of weakened and/or multiple ethnic attachments for future generations of the group (Hout and Goldstein 1994, Perlmann and Waters 2007).

In this section, we explore how intermarriage is associated with the complex ways that Mexicans report their ethnicity and ancestry in U.S. Census data. In the following section, we consider how intermarriage and the Mexican ethnicity/ancestry of parents influence the Mexican identification of children. We show that Mexican intermarriage is highly selective on education and also that having a non-Mexican parent determines, in large part, whether children of Mexican descent are at risk of losing their Mexican identity. Taken together, these findings 
provide a mechanism for selective ethnic attrition among Mexican Americans. Those Mexicans who intermarry tend to have higher levels of human capital, and many of the resulting children are not identified as Mexican in Census data. In this way, selective intermarriage interacts with the intergenerational transmission of human capital and ethnic identity to create a situation in which available data for later-generation Mexican Americans may omit an increasingly large share of the most successful descendants of Mexican immigrants. For the purpose of assessing the empirical importance of such selective ethnic attrition, it is useful to know the extent and selectivity of Mexican intermarriage and of Mexican identification in the subsequent generation. ${ }^{17}$ In this section and the next, we begin to investigate these matters, taking into the account the complexity of Mexican ethnicity/ancestry.

We start with the samples analyzed in the preceding section of U.S.-born men and women ages 25-59 who report Mexican as an ethnicity and/or ancestry. We then identify anyone in these samples who is married (to someone also between the ages of 25-59) and observed to be living in the same Census household as their spouse, and we create a data set that contains information about these marriages, including characteristics of both spouses and any co-resident children. The resulting data set includes marriages that meet the following conditions: both spouses are between the ages of 25-59, the couple currently lives together, and at least one spouse is U.S.-born and reports Mexican as an ethnicity and/or ancestry. Furthermore, we exclude marriages in which either spouse has allocated information about Hispanic origin. These restrictions yield a sample of 71,431 marriages in which either the husband or the wife (or both) is a U.S.-born Mexican.

Table 4 describes the 44,680 marriages in our sample in which the husband is a U.S.-born

\footnotetext{
${ }^{17}$ For this purpose, however, we do not necessarily need to unravel the causal mechanisms driving these processes, and
} 
Mexican. The wives in these marriages may be of any nativity and ethnicity. The row categories of the table indicate the husband's Mexican ethnicity/ancestry group, and the column categories classify wives by nativity and ethnicity/ancestry. Wives are assigned to one of the following four mutually exclusive and exhaustive groups: U.S.-born of Mexican ethnicity, U.S.born of Mexican ancestry (but not of Mexican ethnicity), foreign-born Mexican (i.e., either born in Mexico, or born in some other foreign country and reporting Mexican as an ethnicity and/or ancestry), and "not Mexican” (i.e., all other wives). Therefore, each "cell” of the row and column categories in Table 4 identifies a specific marriage type between a U.S.-born Mexican husband in a particular ethnicity/ancestry group and his wife who belongs to a particular nativity/ethnicity/ancestry group. For each of these cells, the first number reported is the "row percent” showing the percentage of U.S.-born Mexican husbands in a particular ethnicity/ancestry group who have wives of each nativity/ethnicity/ancestry type. These percentages reveal the extent of intermarriage by the U.S.-born Mexican husbands in each ethnicity/ancestry group. The remaining numbers in each cell show average years of schooling (and the corresponding standard errors) for the husbands and wives involved in this particular type of marriage. These numbers give an indication of the selectivity of Mexican intermarriage.

Consider initially the bottom category in Table 4 that includes U.S.-born Mexican husbands from all ethnicity/ancestry groups. Forty-five percent of these Mexican-American men are married to U.S.-born women of Mexican ethnicity, another 6 percent are married to U.S.born women of Mexican ancestry (but not ethnicity), and 13 percent have wives who are Mexican immigrants. The remaining 35 percent of U.S.-born Mexican husbands are intermarried in the sense that their wives are "non-Mexican" (i.e., these wives were not born in 
Mexico and do not list Mexican as an ethnicity or ancestry). Overall, intermarriage is widespread among our sample of Mexican-American husbands, and the vast majority of these intermarriages are to U.S.-born, non-Hispanic white women (Duncan and Trejo 2007).

Moreover, Mexican-American husbands with non-Mexican wives average over a year more schooling than their counterparts who are endogamously married (e.g., 13.2 years versus 12.1 years for husbands with U.S.-born wives of Mexican ethnicity and even lower average schooling levels for husbands with other types of Mexican wives). Table 4 highlights the educational selectivity of Mexican intermarriage, but in previous work we have shown that intermarried Mexican Americans also possess sizeable advantages in English proficiency, employment, and earnings (Duncan and Trejo 2007). Not only do intermarried Mexican-American men have relatively high levels of human capital and labor market performance, their non-Mexican wives display much better outcomes than the Mexican wives of Mexican-American men who are endogamously married. In Table 4, for example, average schooling levels are 13.4 years for the non-Mexican wives of intermarried Mexican-American men, compared to about 12 years for U.S.-born Mexican women in endogamous marriages and 10.3 years for foreign-born Mexican women married to U.S.-born Mexican men. Given overall education levels in Mexico compared to the United States, it is not surprising that Mexican immigrants constitute the least educated group of wives.

In our sample of U.S.-born Mexican husbands, intermarriage is strongly related to their ethnicity/ancestry group. Among those who report a Mexican ethnicity, the intermarriage rate is considerably higher (45 percent) for men who list an ancestry that is neither Mexican nor "general Hispanic.” Most strikingly, the overwhelming majority (83 percent) of U.S.-born men who report a Mexican ancestry but identify their ethnicity as "not Hispanic" are married to non- 
Mexican women. Among U.S.-born men who list a Mexican ancestry and report a "general Hispanic" ethnicity, although only 31 percent have non-Mexican wives, another 53 percent are married to women who report Mexican as their ancestry but not their ethnicity. Note that this last group of Mexican marriages—-between men and women who both list Mexican as their ancestry but not their ethnicity—would be overlooked completely by the standard empirical practice of identifying U.S.-born Mexicans using only the Hispanic origin question. To some extent, Census data may overstate the frequency with which husbands and wives possess exactly the same ethnicity/ancestry, because often one person provides the Census information for all family members, and Lieberson and Waters $(1988,1993)$ present evidence that this and other factors may distort the responses of spouses in the direction of homogeneity. Such a tendency may also cause Census data to understate the frequency of intermarriage.

Although the extent of intermarriage by U.S.-born Mexican men varies across ethnicity/ancestry groups, the educational selectivity of intermarriage is similar for all groups. Within every ethnicity/ancestry group, the average schooling levels of Mexican-American husbands, and of their wives, are much higher in exogamous than endogamous marriages. For example, consider the majority group of husbands who list both their ethnicity and their ancestry as Mexican. Within this group, those whose wives also report a Mexican ethnicity average 12.2 years of schooling (as do their wives), whereas the corresponding schooling levels are over a year higher for intermarried Mexican men (and for their wives).

Table 5 presents analogous information as in Table 4, except that the perspective shifts from the husband's to the wife's, and the sample now consists of the 49,726 marriages in which the wife is a U.S.-born Mexican. In general, the patterns of intermarriage by Mexican-American women in Table 5 are very similar to those that we observed for Mexican-American men in 
Table 4. One gender difference is that marriages between U.S.-born and foreign-born Mexicans are somewhat more likely to involve an immigrant man and a U.S.-born woman, rather than vice-versa. In particular, 17 percent of U.S.-born Mexican wives have husbands who are Mexican immigrants, whereas the corresponding rate of marriage to a foreign-born Mexican is only 13 percent for Mexican-American men.

\section{Mexican Identification of Children}

We next investigate the link between intermarriage in one generation and ethnic identification in the next by examining how the children of U.S.-born Mexicans are identified. ${ }^{18}$ We start with the same sample of Mexican-American marriages from the 2000 Census used in the intermarriage analysis of the preceding section, but henceforth we further restrict the sample to those marriages that have produced at least one child under age 19 currently residing in the household. We continue to exclude marriages in which either spouse has allocated information about Hispanic origin, and we now impose this condition for the relevant children as well. Finally, to the extent possible with the information available in the Census, we exclude families in which any of the children are suspected of being stepchildren. These restrictions produce a sample of 41,434 families in which there is a co-resident child under age 19 and at least one of the parents is a U.S.-born Mexican.

For this sample of families, Table 6 shows how the Mexican identification of the

\footnotetext{
${ }^{18}$ For a wide range of groups, previous research has employed U.S. Census data to investigate the racial/ethnic identification of children in intermarried families. Lieberson and Waters $(1988,1993)$, for example, consider the ancestries assigned to children when the mother's ancestry differs from the father's ancestry. Along the same lines, Xie and Goyette (1997) study the determinants of Asian identification among children produced by intermarriages between an Asian and a non-Asian. Qian (2004) extends this analysis to examine the racial/ethnic identification of children produced by intermarriages between U.S.-born, non-Hispanic whites and several different minority groups: African Americans, Hispanics, Asians, and American Indians.
} 
youngest child varies with the nativity and ethnicity/ancestry of his parents. ${ }^{19}$ The child’s Mexican identification is based on his responses to the Hispanic origin and ancestry questions in the Census. Each child is assigned to one of the following three categories of Mexican identification: Mexican ethnicity, Mexican ancestry (but not of Mexican ethnicity), and “not Mexican” (i.e., all other children). Each child’s family is classified according to the Mexican nativity/ethnicity/ancestry of the parents. The different family types listed in Table 6 are the seven combinations possible in our sample when each parent is assigned to one of the four spousal categories introduced previously in Tables 4 and 5: U.S.-born of Mexican ethnicity, U.S.-born of Mexican ancestry (but not of Mexican ethnicity), foreign-born Mexican, and "not Mexican.”

Table 6 shows that the crucial determinant of a child's Mexican identification is whether both parents identify as Mexican. When both parents are U.S.-born of Mexican ethnicity, or when one parent is U.S.-born of Mexican ethnicity and the other parent is a Mexican immigrant, children are almost always reported to be of Mexican ethnicity (i.e., the relevant rates are 98 percent). In families where one parent is U.S.-born of Mexican ethnicity and the other parent is U.S.-born of Mexican ancestry (but not ethnicity), 63 percent of children are reported to be of Mexican ethnicity, but another 30 percent are reported to be of Mexican ancestry, and so only about 7 percent of these children are identified as “not Mexican.” A very similar percentage of children are identified as "not Mexican” in families where both parents are U.S.-born of Mexican

\footnotetext{
${ }^{19}$ Because Mexican identification varies little across children within a given family, we report results using only information for the youngest child. Instead using information for the oldest child produces similar results, as does incorporating information from any or all of a family's children. We do not know who filled out the Census form, but parents are likely to be responding for their children. An important question is how these children will respond to survey questions about ethnic identification when they answer from themselves. See Portes and Rumbaut (2001, Chapter 7) for a discussion of parental and other influences on the evolving ethnic identities of second-generation adolescents. Eschbach and Gomez (1998) analyze changes in the Hispanic identification of adolescents between the first and second waves, two years apart, of the High School and Beyond panel, and Brown, Hitlin, and Elder (2006) and Perez (2008) do similar types of analyses using data from the National Longitudinal Study of Adolescent Health.
} 
ancestry (but not ethnicity), but in this case the vast majority of children (88 percent) are reported to be of Mexican ancestry and relatively few (5 percent) are identified as being of Mexican ethnicity. In intermarriages between a U.S.-born Mexican and a non-Mexican, however, the chances that the child does not retain any Mexican identification rises sharply, to 21 percent if the Mexican-American parent reports a Mexican ethnicity, and all the way to 58 percent if this parent only claims a Mexican ancestry. Overall, in our sample of children who have at least one Mexican-American parent, the bottom row of Table 6 indicates that only about three-quarters of these children are identified as Mexican by the standard measure (i.e., the Hispanic origin question), whereas 12 percent report a Mexican ancestry (but not a Mexican ethnicity), and 13 percent do not retain any Mexican identification.

Table 6 suggests that intermarriage plays a key role in the loss of Mexican identity by children of Mexican descent. Earlier, in Tables 4 and 5, we saw that Mexican intermarriage is highly selective on education, and other work has shown, more generally, that Mexican intermarriage is also highly selective on English proficiency, employment, and earnings (Duncan and Trejo 2007). Taken together, the positive selectivity of Mexican intermarriage and the strong influence of intermarriage on children’s ethnic identification imply that MexicanAmerican children with weaker attachment to their Mexican identity should have, on average, parents with higher levels of human capital.

Table 7 confirms this implication. The educational attainment and English proficiency of both fathers and mothers rise as the Mexican identification of the youngest child fades from Mexican ethnicity to Mexican ancestry to "not Mexican.” The average schooling of fathers, for example, is more than a year higher for children identified as “not Mexican” compared to children of Mexican ethnicity. Moreover, children of Mexican ethnicity have fathers who are 
over three times as likely to speak deficient English as the fathers of children identified as "not Mexican.” For mothers, the patterns are similar but slightly less pronounced. These data indicate how selective intermarriage might interact with the parent-child transmission of human capital and ethnic identification to bias observed measures of socioeconomic attainment for later generations of Mexican Americans. In particular, the kind of selective ethnic attrition observed in Table 7 suggests that available data may understate the intergenerational progress of the descendents of Mexican immigrants, but this analysis can only shed light on the direction, not the magnitude, of any such measurement bias. ${ }^{20}$

\section{Conclusion}

In this paper, we explore some of the multifaceted ways that Mexican Americans identify themselves in 2000 U.S. Census data. Our analysis highlights the complexity of ethnic identification for Mexican Americans, particularly for those born in the United States. In our samples of U.S.-born men and women who give some indication that they are of Mexican descent, just over two-thirds of these individuals answer "Mexican” to both the Hispanic origin and the ancestry questions in the Census. About 20 percent report a Mexican ethnicity (in response to the Hispanic origin question) but do not list a Mexican ancestry, and the remaining 11-12 percent identify as Mexican in response to the ancestry question but not the Hispanic origin question. Within these broad categories, there is considerable variation in the particular

\footnotetext{
${ }^{20}$ To estimate the magnitude of the bias from selective ethnic attrition, we would need to measure the full extent of this attrition, which is not possible with the data used here. In our Census samples, for us to know that a child with U.S.-born parents is of Mexican descent, at least one of his parents must continue to self-identify as Mexican (in response to the Hispanic origin and/or ancestry questions). We therefore miss completely any Mexican-origin families in which the relevant Mexican descendants no longer identify as Mexican. Data from the 1970 Census Content Reinterview Study, presented in Table 2 of Duncan and Trejo (2007), indicate that we could be missing a large share of later-generation Mexican-origin families (e.g., over half of Mexican descendants beyond the third generation). In recent years, the Current Population Survey has asked respondents about their parents' countries of birth, information that the U.S. Census stopped collecting after 1970. See Duncan and Trejo
} 
non-Mexican responses given for ethnicity or ancestry.

The ethnicity/ancestry combinations chosen by U.S.-born Mexicans are strongly related to important human capital measures (education and English proficiency) as well as to key labor market outcomes (employment and hourly earnings). In particular, human capital and earnings are highest for U.S.-born Mexicans who identify their ethnicity as “not Hispanic” and lowest for those who do not report an ancestry. Compared to the majority group that lists Mexican as both their ethnicity and their ancestry, persons who report a pan-ethnic “general Hispanic” ethnicity or ancestry also possess relatively low human capital and earnings. These patterns remain strong even after controlling for age and geographic location, and the human capital differences across Mexican ethnicity/ancestry groups account for part but not all of the corresponding earnings differences.

Persons who list a Mexican ancestry but do not report a Mexican ethnicity are especially interesting. Such individuals typically are excluded from empirical research on Mexican Americans, because most studies use only the Hispanic origin question to identify U.S.-born persons of Mexican descent. We show that these excluded Mexicans split into two quite distinct groups. Those who report a “general Hispanic” ethnicity have somewhat lower levels of educational attainment, English proficiency, and earnings than are observed in the overall samples of U.S.-born Mexican men and women. In contrast, persons who list a Mexican ancestry but simultaneously report their ethnicity as “not Hispanic” have much higher levels of human capital and earnings than any other ethnicity/ancestry group of U.S.-born Mexicans.

Reported ethnicity/ancestry also influences the extent and selectivity of Mexican intermarriage and the Mexican identification of the resulting children. Marriage to non- 
Mexicans is the norm for U.S.-born persons who report a Mexican ancestry but identify their ethnicity as “not Hispanic.” Moreover, the average schooling levels of Mexican Americans, and of their spouses, are much higher in exogamous than endogamous marriages. Finally, we present evidence that intermarriage plays a key role in the loss of Mexican identity by children of Mexican descent. Taken together, the positive selectivity of Mexican intermarriage and the strong influence of intermarriage on children's ethnic identification imply that MexicanAmerican children with weaker attachment to their Mexican identity should have, on average, parents with higher levels of human capital. We show that this is indeed the case.

In particular, persons of Mexican ancestry who identify their ethnicity as "not Hispanic" seem to provide a prime example of ethnic attrition in which the attrition is "positively" selected, similar to what we found in our previous analyses of intermarriage and ethnic identification by Mexican Americans (Duncan and Trejo 2007, 2008). U.S.-born Mexicans in this group possess relatively high levels of human capital and earnings, they intermarry frequently, and as a result their children often do not retain any Mexican identification. This group illustrates how selective intermarriage might interact with the parent-child transmission of human capital and ethnic identification so as to make available data understate the intergenerational progress of the descendents of Mexican immigrants. The potential for this type of measurement bias is important for assessing the socioeconomic attainment of the Mexican-origin population in the United States and for designing policies to help this population. Our findings here, however, can only shed light on the direction, not the magnitude, of any such bias.

More generally, our analysis suggests that research and policy concerning Mexican Americans could benefit from greater attention to the complexity of ethnic identification. Recent 
work in economics has demonstrated that a nuanced view of ethnic identity generates new insights for the study of immigrant assimilation (Constant and Zimmermann 2007; Zimmermann 2007). Here we show that this same point can also apply to the study of native-born minority populations. 


\section{References}

Akerlof, George A., and Kranton, Rachel E. “Economics and Identity.” Quarterly Journal of Economics, August 2000, 115(3), pp. 715-53.

Alba, Richard D. Italian Americans: Into the Twilight of Ethnicity. Englewood Cliffs, NJ: Prentice-Hall, 1986. . Ethnic Identity: The Transformation of White America. New Haven, CT: Yale University Press, 1990.

Alba, Richard D., and Chamlin, Mitchell B. "A Preliminary Examination of Ethnic Identification among Whites.” American Sociological Review, April 1983, 48(2), pp. 240-47.

Alba, Richard D., and Islam, Tariqul. "The Case of the Disappearing Mexican Americans: An Ethnic-Identity Mystery.” Population Research and Policy Review, forthcoming 2008.

Alba, Richard D., and Nee, Victor. Rethinking the American Mainstream: Assimilation and Contemporary Immigration. Cambridge, MA: Harvard University Press, 2003.

Bisin, Alberto; Topa, Giorgio; and Verdier, Thierry. "Religious Intermarriage and Socialization in the United States.” Journal of Political Economy, June 2004, 112(3), pp. 615-64.

Bisin, Alberto, and Verdier, Thierry. “ 'Beyond the Melting Pot': Cultural Transmission, Marriage, and the Evolution of Ethnic and Religious Traits.” Quarterly Journal of Economics, August 2000, 115(3), pp. 955-88.

Blau, Francine D., and Kahn, Lawrence M. “Gender and Assimilation among Mexican Americans,” in George J. Borjas, ed., Mexican Immigration to the United States. Chicago: University of Chicago Press, 2007, pp. 57-106.

Bodenhorn, Howard, and Ruebeck, Christopher S. "Colourism and African-American Wealth: Evidence from the Nineteenth-Century South.” Journal of Population Economics, July 2007, 20(3), pp. 599-620.

Borjas, George J. “The Intergenerational Mobility of Immigrants.” Journal of Labor Economics, January 1993, Part 1, 11(1), pp. 113-35.

- "Long-Run Convergence of Ethnic Skill Differentials: The Children and Grandchildren of the Great Migration.” Industrial and Labor Relations Review, July 1994, 47(4), pp. 553-73.

Brown, J. Scott; Hitlin, Steven; and Elder, Jr., Glen H. “The Greater Complexity of Lived Race: 
An Extension of Harris and Sim.” Social Science Quarterly, June 2006, 87(2), pp. 41131.

Card, David; DiNardo, John; and Estes, Eugena. “The More Things Change: Immigrants and the Children of Immigrants in the 1940s, the 1970s, and the 1990s,” in George J. Borjas, ed., Issues in the Economics of Immigration. Chicago: University of Chicago Press, 2000, pp. 227-69.

Choi, Kate H.; Sakamoto, Arthur; and Powers, Daniel. "Who is Hispanic? Hispanic Identity among African Americans, Asian Americans, Others, and Whites.” Sociological Inquiry, forthcoming 2008.

Constant, Amelie; Gataullina, Liliya; and Zimmermann, Klaus F. “Gender, Ethnic Identity and Work.” Discussion Paper no. 2420. Bonn, Germany: IZA, November 2006.

Constant, Amelie, and Zimmermann, Klaus F. "Measuring Ethnic Identity and Its Impact on Economic Behavior.” Discussion Paper no. 3063. Bonn, Germany: IZA, September 2007.

Cresce, Arthur R., and Ramirez, Roberto R. “Analysis of General Hispanic Responses in Census 2000.” Working Paper 72. Washington, DC: U.S. Bureau of the Census, Population Division, September 2003.

Darity, Jr., William A.; Hamilton, Darrick; and Dietrich, Jason. "Passing on Blackness: Latinos, Race, and Earnings in the USA.” Applied Economics Letters, October 2002, 9(13), pp. 847-53.

Darity, Jr., William A.; Mason, Patrick L.; and Stewart, James B. "The Economics of Identity: The Origin and Persistence of Racial Norms.” Journal of Economic Behavior \& Organization, July 2006, 60(3), pp. 283-305.

del Pinal, Jorge H. Race and Ethnicity in Census 2000. Census 2000 Testing, Experimentation, and Evaluation Program: Topic Report No. 9. Washington, DC: U.S. Census Bureau, March 2004.

Duncan, Brian; Hotz, V. Joseph; and Trejo, Stephen J. “Hispanics in the U.S. Labor Market,” in Marta Tienda and Faith Mitchell, eds., Hispanics and the Future of America.

Washington, DC: National Academies Press, 2006, pp. 228-90.

Duncan, Brian, and Trejo, Stephen J. "Ethnic Identification, Intermarriage, and Unmeasured Progress by Mexican Americans,” in George J. Borjas, ed., Mexican Immigration to the United States. Chicago: University of Chicago Press, 2007, pp. 227-69.

. "Intermarriage and the Intergenerational Transmission of Ethnic Identity and Human Capital for Mexican Americans.” Manuscript. Austin: University of Texas, May 2008. 
Emeka, Amon. "Who are the Hispanic Non-Hispanics and Why Do They Matter? Toward a More Inclusive Definition of the Hispanic Population.” Manuscript. Los Angeles: University of Southern California, January 2008.

Eschbach, Karl. "The Enduring and Vanishing American Indian: American Indian Population Growth and Intermarriage in 1990.” Ethnic and Racial Studies, January 1995, 18(1), pp. 89-108.

Eschbach, Karl, and Gomez, Christina. "Choosing Hispanic Identity: Ethnic Identity Switching among Respondents to High School and Beyond.” Social Science Quarterly, March 1998, 79(1), pp. 74-90.

Eschbach, Karl; Supple, Khalil; and Snipp, C. Matthew. "Changes in Racial Identification and the Educational Attainment of American Indians, 1970-1990.” Demography, February 1998, 35(1), pp. 35-43.

Farley, Reynolds. “The New Census Question about Ancestry: What Did It Tell Us?” Demography, August 1991, 28(3), pp. 411-29.

Farley, Reynolds, and Alba, Richard. “The New Second Generation in the United States.” International Migration Review, Fall 2002, 36(3), pp. 669-701.

Fry, Richard, and Lowell, B. Lindsay. "Work or Study: Different Fortunes of U.S. Latino Generations.” Report. Washington, DC: Pew Hispanic Center, 2002.

Gans, Herbert J. "Second-Generation Decline: Scenarios for the Economic and Ethnic Futures of the Post-1965 American Immigrants.” Ethnic and Racial Studies, April 1992, 15(2), pp. 173-92.

Ghazal Read, Jen’nan. “Alternative Definitions of Mexican and Arab Identity: Demographic and Socioeconomic Implications.” Manuscript. Irvine, CA: University of California at Irvine, 2005.

Gordon, Milton M. Assimilation in American Life: The Role of Race, Religion, and National Origins. New York: Oxford University Press, 1964.

Grieco, Elizabeth M., and Cassidy, Rachel C. Overview of Race and Hispanic Origin. Census 2000 Brief C2KBR/01-1. Washington, DC: U.S. Census Bureau, March 2001.

Grogger, Jeffrey, and Trejo, Stephen J. Falling Behind or Moving Up? The Intergenerational Progress of Mexican Americans. San Francisco: Public Policy Institute of California, 2002.

Hout, Michael, and Goldstein, Joshua R. "How 4.5 Million Irish Immigrants Became 40 Million Irish Americans: Demographic and Subjective Aspects of the Ethnic Composition of White Americans.” American Sociological Review, February 1994, 59(1), pp. 64-82. 
Huntington, Samuel P. Who Are We?: The Challenges to America's Identity. New York: Simon and Schuster, 2004.

Jaeger, David A. "Reconciling the Old and New Census Bureau Education Questions: Recommendations for Researchers.” Journal of Business and Economics Statistics, July 1997, 15(3), pp. 300-09.

Lieberson, Stanley, and Waters, Mary C. From Many Strands: Ethnic and Racial Groups in Contemporary America. New York: Russell Sage Foundation, 1988.

. "The Ethnic Responses of Whites: What Causes Their Instability, Simplification, and Inconsistency?” Social Forces, December 1993, 72(2), pp. 421-50.

Livingston, Gretchen, and Kahn, Joan R. “An American Dream Unfulfilled: The Limited Mobility of Mexican Americans.” Social Science Quarterly, December 2002, 83(4), pp. 1003-12.

Logan, John R. "Hispanic Populations and Their Residential Patterns in the Metropolis.” Lewis Mumford Center Report. Albany, NY: State University of New York at Albany, May 2002.

Manning, Alan, and Roy, Sanchari. "Culture Clash or Culture Club? The Identity and Attitudes of Immigrants in Britain.” Discussion Paper no. 790. London: Centre for Economic Performance, London School of Economics and Political Science, April 2007.

Mason, Patrick L. "Annual Income, Hourly Wages, and Identity Among Mexican Americans and Other Latinos.” Industrial Relations, October 2004, 43(4), pp. 817-34.

Nekby, Lena, and Rodin, Magnus. “Acculturation Identity and Labor Market Outcomes.” Discussion Paper no. 2826. Bonn, Germany: IZA, June 2007.

Ono, Hiromi. “Assimilation, Ethnic Competition, and Ethnic Identities of U.S.-Born Persons of Mexican Origin.” International Migration Review, Fall 2002, 36(3), pp. 726-45.

Perez, Anthony D. "Who is Hispanic? Shades of Ethnicity among Latino/a Youth.” Social Forces, forthcoming 2008.

Perlmann, Joel. Italians Then, Mexicans Now: Immigrant Origins and Second-Generation Progress, 1890-2000. New York: Russell Sage Foundation, 2005.

Perlmann, Joel, and Waters, Mary C. "Intermarriage Then and Now: Race, Generation, and the Changing Meaning of Marriage,” in Nancy Foner and George M. Fredrickson, eds., Not Just Black and White: Historical and Contemporary Perspectives on Immigration, Race, and Ethnicity in the United States. New York: Russell Sage Foundation, 2004, pp. 26277. 
"Intermarriage and Multiple Identities,” in Mary C. Wagers and Reed Udea, eds., The New Americans: A Guide to Immigration Since 1965. Cambridge, MA: Harvard University Press, 2007, pp. 110-123.

Portes, Alejandro, and Rumbaut, Ruben G. Legacies: The Story of the Immigrant Second Generation. Berkeley, CA: University of California Press, 2001.

Portes, Alejandro, and Zhou, Min. “The New Second Generation: Segmented Assimilation and Its Variants Among Post-1965 Immigrant Youth.” Annals of the American Academy of Political and Social Science, November 1993, 530, pp. 74-96.

Qian, Zhenchao. “Options: Racial/Ethnic Identification of Children of Intermarried Couples.” Social Science Quarterly, September 2004, 85(3), pp. 746-66.

Rosenfeld, Michael J. "Measures of Assimilation in the Marriage Market: Mexican Americans 1970-1990.” Journal of Marriage and Family, February 2002, 64(1), pp. 152-62.

Rumbaut, Ruben G. “The Crucible Within: Ethnic Identity, Self-Esteem, and Segmented Assimilation Among Children of Immigrants.” International Migration Review, Winter 1994, 28(4), pp. 748-94.

Smith, James P. “Assimilation across the Latino Generations.” American Economic Review, May 2003, 93(2), pp. 315-319.

Snipp, C. Matthew. American Indians: The First of this Land. New York: Russell Sage Foundation, 1989.

Stephan, Cookie White, and Stephan, Walter G. “After Intermarriage: Ethnic Identity among Mixed-Heritage Japanese-Americans and Hispanics.” Journal of Marriage and the Family, May 1989, 51(2), pp. 507-19.

Trejo, Stephen J. “Why Do Mexican Americans Earn Low Wages?” Journal of Political Economy, December 1997, 105(6), pp. 1235-68.

- "Intergenerational Progress of Mexican-Origin Workers in the U.S. Labor Market." Journal of Human Resources, Summer 2003, 38(3), pp. 467-89.

Waters, Mary C. Ethnic Options: Choosing Identities in America. Berkeley, CA: University of California Press, 1990.

White, Halbert. “A Heteroskedasticity-Consistent Covariance Matrix Estimator and a Direct test for Heteroskedasticity.” Econometrica, May 1980, 48(4), pp. 817-38.

Xie, Yu, and Goyette, Kimberly. "The Racial Identification of Biracial Children with One Asian Parent: Evidence from the 1990 Census.” Social Forces, December 1997, 76(2), pp. 547- 
70.

Zimmermann, Klaus F. “Migrant Ethnic Identity: Concept and Policy Implications.” Discussion Paper no. 3056. Bonn, Germany: IZA, September 2007. 
Figure 1: 2000 Census Questions Regarding Hispanic Origin and Ancestry

NOTE: Please answer BOTH Questions 5 and 6.

5. Is this person Spanish/Hispanic/Latino? Mark [X] the "No" box if not Spanish/Hispanic/Latino.

O No, not Spanish/Hispanic/Latino

O Yes, Mexican, Mexican Am., Chicano

O Yes, Puerto Rican

O Yes, Cuban

O Yes, other Spanish/Hispanic/Latino - Print group.

[][][][][][][][][][][][][][][]

[][][][][][][][][][][][][][][]

6. What is this person's race? Mark [X] one or more races to indicate what this person considers himself/herself to be.

10. What is this person's ancestry or ethnic origin?

[][][][][][][][][][][][][][][]

$[\mathrm{]}[\mathrm{]}[\mathrm{]}[\mathrm{]}][\mathrm{]}][\mathrm{]}[\mathrm{]}[\mathrm{]}] \mathrm{]}][\mathrm{]}][\mathrm{]}][\mathrm{]}]$

(For example: Italian, Jamaican, African Am., Cambodian, Cape Verdean, Norwegian, Dominican, French Canadian, Haitian, Korean, Lebanese, Polish, Nigerian, Mexican, Taiwanese, Ukrainian, and so on.) 


\section{Table 1: Reported Ethnicity and Ancestry of Mexican Americans}

\begin{tabular}{|c|c|c|c|c|}
\hline & \multicolumn{2}{|c|}{$\begin{array}{c}\text { Individuals } \\
\text { Born in Mexico }\end{array}$} & \multicolumn{2}{|c|}{$\begin{array}{l}\text { U.S.-born Individuals } \\
\text { of Mexican Ethnicity } \\
\text { and/or Ancestry }\end{array}$} \\
\hline & Men & Women & Men & Women \\
\hline \multicolumn{5}{|l|}{ Ethnicity: } \\
\hline Mexican & 93.6 & 92.7 & 88.8 & 87.5 \\
\hline General Hispanic & 5.2 & 5.9 & 8.0 & 9.2 \\
\hline Other Hispanic & 0.4 & 0.4 & 0.1 & 0.1 \\
\hline \multirow[t]{2}{*}{ Not Hispanic } & 0.8 & 1.0 & 3.1 & 3.1 \\
\hline & $100.0 \%$ & $100.0 \%$ & $100.0 \%$ & $100.0 \%$ \\
\hline \multicolumn{5}{|l|}{ Ancestry: } \\
\hline Mexican & 85.6 & 85.2 & 79.0 & 81.0 \\
\hline General Hispanic & 5.1 & 5.3 & 7.9 & 8.8 \\
\hline Other ancestry & 3.0 & 2.7 & 3.6 & 3.8 \\
\hline \multirow[t]{2}{*}{ Not reported } & 6.4 & 6.8 & 9.5 & 6.4 \\
\hline & $100.0 \%$ & $100.0 \%$ & $100.0 \%$ & $100.0 \%$ \\
\hline \multicolumn{5}{|l|}{ Ethnicity/Ancestry: } \\
\hline \multicolumn{5}{|l|}{ Ethnicity is Mexican and Ancestry is } \\
\hline Mexican & 81.5 & 80.6 & 67.8 & 68.5 \\
\hline General Hispanic & 4.3 & 4.4 & 7.9 & 8.8 \\
\hline Other ancestry & 2.4 & 2.1 & 3.6 & 3.8 \\
\hline Not reported & 5.3 & 5.6 & 9.5 & 6.4 \\
\hline \multicolumn{5}{|l|}{ Ancestry is Mexican and Ethnicity is } \\
\hline General Hispanic & 3.6 & 4.2 & 8.0 & 9.2 \\
\hline Other Hispanic & 0.1 & 0.1 & 0.1 & 0.1 \\
\hline Not Hispanic & 0.4 & 0.4 & 3.1 & 3.1 \\
\hline \multirow[t]{2}{*}{ Neither Ethnicity nor Ancestry is Mexican } & 2.4 & 2.7 & 0.0 & 0.0 \\
\hline & $100.0 \%$ & $100.0 \%$ & $100.0 \%$ & $100.0 \%$ \\
\hline
\end{tabular}

Source: 2000 U.S. Census data.

Note: The samples include men and women ages 25-59 who were either (1) born in Mexico, or (2) born in the United States and report Mexican as an ethnicity and/or ancestry. For those born in Mexico, the sample sizes are 152,103 men and 121,955 women. For those born in the United States, the sample sizes are 88,989 men and 92,644 women. 


\section{Table 2: Average Outcomes by Mexican Ethnicity/Ancestry}

\begin{tabular}{|c|c|c|c|c|}
\hline & $\begin{array}{c}\text { Years of } \\
\text { Education }\end{array}$ & $\begin{array}{c}\text { Deficient } \\
\text { English }\end{array}$ & $\begin{array}{c}\text { Percent } \\
\text { Employed }\end{array}$ & $\begin{array}{l}\text { Log Hourly } \\
\text { Earnings }\end{array}$ \\
\hline \multicolumn{5}{|l|}{ Men } \\
\hline \multicolumn{5}{|c|}{ Ethnicity/Ancestry: } \\
\hline \multicolumn{5}{|c|}{ Ethnicity is Mexican and Ancestry is } \\
\hline Mexican & $\begin{array}{l}12.3 \\
(.01)\end{array}$ & $\begin{array}{l}13.1 \\
(.14)\end{array}$ & $\begin{array}{l}89.0 \\
(.13)\end{array}$ & $\begin{array}{l}2.644 \\
(.003)\end{array}$ \\
\hline General Hispanic & $\begin{array}{c}12.1 \\
(.03)\end{array}$ & $\begin{array}{c}10.8 \\
(.37)\end{array}$ & $\begin{array}{r}86.9 \\
(.40)\end{array}$ & $\begin{array}{l}2.586 \\
(.008)\end{array}$ \\
\hline Other ancestry & $\begin{array}{c}12.3 \\
(.05)\end{array}$ & $\begin{array}{l}9.7 \\
(.53)\end{array}$ & $\begin{array}{r}84.7 \\
(.64)\end{array}$ & $\begin{array}{l}2.610 \\
(.013)\end{array}$ \\
\hline Not reported & $\begin{array}{r}10.7 \\
(.04)\end{array}$ & $\begin{array}{r}16.5 \\
(.40)\end{array}$ & $\begin{array}{l}70.1 \\
(.50)\end{array}$ & $\begin{array}{l}2.484 \\
(.009)\end{array}$ \\
\hline \multicolumn{5}{|c|}{ Ancestry is Mexican and Ethnicity is } \\
\hline General or other Hispanic & $\begin{array}{l}11.9 \\
(.03)\end{array}$ & $\begin{array}{l}15.0 \\
(.42)\end{array}$ & $\begin{array}{l}88.7 \\
(.37)\end{array}$ & $\begin{array}{l}2.561 \\
(.008)\end{array}$ \\
\hline Not Hispanic & $\begin{array}{c}12.9 \\
(.05)\end{array}$ & $\begin{array}{l}3.8 \\
(.37)\end{array}$ & $\begin{array}{l}89.9 \\
(.57)\end{array}$ & $\begin{array}{l}2.748 \\
(.014)\end{array}$ \\
\hline All men & $\begin{array}{l}12.1 \\
(.01)\end{array}$ & $\begin{array}{c}13.0 \\
(.11)\end{array}$ & $\begin{array}{l}86.9 \\
(.11)\end{array}$ & $\begin{array}{l}2.623 \\
(.002)\end{array}$ \\
\hline \multicolumn{5}{|l|}{ Women } \\
\hline \multicolumn{5}{|c|}{ Ethnicity/Ancestry: } \\
\hline \multicolumn{5}{|c|}{ Ethnicity is Mexican and Ancestry is } \\
\hline Mexican & $\begin{array}{l}12.3 \\
(.01)\end{array}$ & $\begin{array}{l}12.4 \\
(.13)\end{array}$ & $\begin{array}{l}77.4 \\
(.17)\end{array}$ & $\begin{array}{l}2.453 \\
(.003)\end{array}$ \\
\hline General Hispanic & $\begin{array}{c}12.1 \\
(.03)\end{array}$ & $\begin{array}{l}9.8 \\
(.33)\end{array}$ & $\begin{array}{l}75.6 \\
(.47)\end{array}$ & $\begin{array}{l}2.371 \\
(.008)\end{array}$ \\
\hline Other ancestry & $\begin{array}{c}12.3 \\
(.05)\end{array}$ & $\begin{array}{l}7.5 \\
(.44)\end{array}$ & $\begin{array}{r}72.7 \\
(.75)\end{array}$ & $\begin{array}{l}2.417 \\
(.013)\end{array}$ \\
\hline Not reported & $\begin{array}{l}10.9 \\
(.05)\end{array}$ & $\begin{array}{l}17.2 \\
(.49)\end{array}$ & $\begin{array}{r}64.1 \\
(.63)\end{array}$ & $\begin{array}{l}2.353 \\
(.011)\end{array}$ \\
\hline \multicolumn{5}{|c|}{ Ancestry is Mexican and Ethnicity is } \\
\hline General or other Hispanic & $\begin{array}{l}11.9 \\
(.03)\end{array}$ & $\begin{array}{l}15.5 \\
(.39)\end{array}$ & $\begin{array}{l}77.0 \\
(.45)\end{array}$ & $\begin{array}{l}2.346 \\
(.008)\end{array}$ \\
\hline Not Hispanic & $\begin{array}{c}12.9 \\
(.04)\end{array}$ & $\begin{array}{l}3.8 \\
(.36)\end{array}$ & $\begin{array}{c}77.9 \\
(.77)\end{array}$ & $\begin{array}{l}2.534 \\
(.014)\end{array}$ \\
\hline All women & $\begin{array}{l}12.2 \\
(.01)\end{array}$ & $\begin{array}{c}12.3 \\
(.11)\end{array}$ & $\begin{array}{c}76.2 \\
(.14)\end{array}$ & $\begin{array}{l}2.432 \\
(.002)\end{array}$ \\
\hline
\end{tabular}

Source: 2000 U.S. Census data.

Note: Standard errors are shown in parentheses. The samples include U.S.-born men and women ages 25-59 who report Mexican as an ethnicity and/or ancestry. The samples for the hourly earnings data are further limited to individuals who were employed at some time during the calendar year preceding the Census. The sample sizes are 88,989 men and 92,644 women for the full samples, and 76,108 men and 69,043 women for the earnings samples. 


\section{Table 3: Regression-Adjusted Outcome Differences by Mexican Ethnicity/Ancestry}

\begin{tabular}{|c|c|c|c|c|c|c|}
\hline \multirow{3}{*}{ Regressor } & \multicolumn{6}{|c|}{ Dependent Variable } \\
\hline & \multirow{2}{*}{$\begin{array}{c}\text { Years of } \\
\text { Education } \\
\end{array}$} & \multirow{2}{*}{$\begin{array}{l}\text { Deficient } \\
\text { English } \\
\end{array}$} & \multicolumn{2}{|c|}{ Employment } & \multicolumn{2}{|c|}{ Log Hourly Earnings } \\
\hline & & & $(1)$ & $(2)$ & $(1)$ & $(2)$ \\
\hline \multicolumn{7}{|l|}{ Men } \\
\hline \multicolumn{7}{|c|}{ Ethnicity/Ancestry: } \\
\hline \multicolumn{7}{|c|}{$\begin{array}{l}\text { Ethnicity is Mexican and Ancestry is } \\
\text { Mexican (reference group) }\end{array}$} \\
\hline General Hispanic & $\begin{array}{l}-.17 \\
(.03)\end{array}$ & $\begin{array}{l}-.026 \\
(.004)\end{array}$ & $\begin{array}{l}-.022 \\
(.004)\end{array}$ & $\begin{array}{l}-.019 \\
(.004)\end{array}$ & $\begin{array}{l}-.034 \\
(.008)\end{array}$ & $\begin{array}{l}-.026 \\
(.008)\end{array}$ \\
\hline Other ancestry & $\begin{array}{l}-.05 \\
(.05)\end{array}$ & $\begin{array}{l}-.028 \\
(.005)\end{array}$ & $\begin{array}{l}-.046 \\
(.006)\end{array}$ & $\begin{array}{l}-.046 \\
(.006)\end{array}$ & $\begin{array}{l}-.039 \\
(.013)\end{array}$ & $\begin{array}{l}-.039 \\
(.012)\end{array}$ \\
\hline Not reported & $\begin{array}{c}-1.58 \\
(.04)\end{array}$ & $\begin{array}{l}.034 \\
(.004)\end{array}$ & $\begin{array}{l}-.190 \\
(.005)\end{array}$ & $\begin{array}{l}-.156 \\
(.005)\end{array}$ & $\begin{array}{l}-.148 \\
(.009)\end{array}$ & $\begin{array}{l}-.053 \\
(.009)\end{array}$ \\
\hline \multicolumn{7}{|c|}{ Ancestry is Mexican and Ethnicity is } \\
\hline General or other Hispanic & $\begin{array}{l}-.30 \\
(.03)\end{array}$ & $\begin{array}{l}.001 \\
(.004)\end{array}$ & $\begin{array}{l}-.001 \\
(.004)\end{array}$ & $\begin{array}{l}.005 \\
(.004)\end{array}$ & $\begin{array}{l}-.038 \\
(.008)\end{array}$ & $\begin{array}{l}-.019 \\
(.008)\end{array}$ \\
\hline Not Hispanic & $\begin{array}{l}.56 \\
(.05)\end{array}$ & $\begin{array}{l}-.083 \\
(.004)\end{array}$ & $\begin{array}{l}.003 \\
(.006)\end{array}$ & $\begin{array}{l}-.012 \\
(.006)\end{array}$ & $\begin{array}{l}.094 \\
(.014)\end{array}$ & $\begin{array}{l}.054 \\
(.013)\end{array}$ \\
\hline Years of education & & & & $\begin{array}{l}.021 \\
(.0005)\end{array}$ & & $\begin{array}{l}.062 \\
(.001)\end{array}$ \\
\hline Deficient English & & & & $\begin{array}{l}-.033 \\
(.004)\end{array}$ & & $\begin{array}{l}-.063 \\
(.007)\end{array}$ \\
\hline \multicolumn{7}{|l|}{ Women } \\
\hline \multicolumn{7}{|c|}{$\begin{array}{l}\text { Ethnicity is Mexican and Ancestry is } \\
\text { Mexican (reference group) }\end{array}$} \\
\hline General Hispanic & $\begin{array}{l}-.26 \\
(.03)\end{array}$ & $\begin{array}{l}-.028 \\
(.004)\end{array}$ & $\begin{array}{l}-.021 \\
(.005)\end{array}$ & $\begin{array}{l}-.013 \\
(.005)\end{array}$ & $\begin{array}{l}-.057 \\
(.008)\end{array}$ & $\begin{array}{l}-.036 \\
(.008)\end{array}$ \\
\hline Other ancestry & $\begin{array}{l}-.13 \\
(.05)\end{array}$ & $\begin{array}{l}-.039 \\
(.005)\end{array}$ & $\begin{array}{l}-.052 \\
(.008)\end{array}$ & $\begin{array}{l}-.050 \\
(.007)\end{array}$ & $\begin{array}{l}-.046 \\
(.013)\end{array}$ & $\begin{array}{l}-.043 \\
(.013)\end{array}$ \\
\hline Not reported & $\begin{aligned}-1.40 \\
(.05)\end{aligned}$ & $\begin{array}{l}.044 \\
(.005)\end{array}$ & $\begin{array}{l}-.129 \\
(.006)\end{array}$ & $\begin{array}{l}-.075 \\
(.006)\end{array}$ & $\begin{array}{l}-.092 \\
(.011)\end{array}$ & $\begin{array}{l}.003 \\
(.011)\end{array}$ \\
\hline \multicolumn{7}{|c|}{ Ancestry is Mexican and Ethnicity is } \\
\hline General or other Hispanic & $\begin{array}{l}-.28 \\
(.03)\end{array}$ & $\begin{array}{l}.014 \\
(.004)\end{array}$ & $\begin{array}{l}.001 \\
(.005)\end{array}$ & $\begin{array}{l}.012 \\
(.005)\end{array}$ & $\begin{array}{l}-.058 \\
(.008)\end{array}$ & $\begin{array}{l}-.032 \\
(.008)\end{array}$ \\
\hline Not Hispanic & $\begin{array}{l}.42 \\
(.05)\end{array}$ & $\begin{array}{l}-.070 \\
(.004)\end{array}$ & $\begin{array}{l}-.006 \\
(.008)\end{array}$ & $\begin{array}{l}-.027 \\
(.008)\end{array}$ & $\begin{array}{l}.079 \\
(.014)\end{array}$ & $\begin{array}{l}.050 \\
(.013)\end{array}$ \\
\hline Years of education & & & & $\begin{array}{l}.036 \\
(.0005)\end{array}$ & & $\begin{array}{l}.079 \\
(.001)\end{array}$ \\
\hline Deficient English & & & & $\begin{array}{l}-.072 \\
(.005)\end{array}$ & & $\begin{array}{l}-.030 \\
(.008)\end{array}$ \\
\hline
\end{tabular}

Source: 2000 U.S. Census data.

Note: The reported figures are estimated coefficients from ordinary least squares regressions run separately for men and women. Heteroskedasticity-robust standard errors are shown in parentheses. The samples include U.S.-born men and women ages 25-59 who report Mexican as an ethnicity and/or ancestry. The samples for the hourly earnings regressions are further limited to individuals who were employed at some time during the calendar year preceding the Census. The sample sizes are 88,989 men and 92,644 women for the full samples, and 76,108 men and 69,043 women for the earnings samples. All regressions control for the respondent's geographic location and age. The controls for geographic location are dummy variables identifying the nine Census divisions, the individual states of California and Texas, and whether the respondent resides in a metropolitan area. The controls for age are dummy variables identifying five-year age intervals. 


\section{Table 4: The Extent and Selectivity of Intermarriage by U.S.-born Mexican Husbands}

\begin{tabular}{|c|c|c|c|c|c|}
\hline \multirow[b]{2}{*}{ Husband's Ethnicity/Ancestry } & \multicolumn{5}{|c|}{ Nativity and Mexican Ethnicity/Ancestry of Wife } \\
\hline & $\begin{array}{l}\text { U.S.-born of } \\
\text { Mexican } \\
\text { Ethnicity } \\
\end{array}$ & $\begin{array}{l}\text { U.S.-born of } \\
\text { Mexican } \\
\text { Ancestry }\end{array}$ & $\begin{array}{c}\text { Foreign-born } \\
\text { Mexican } \\
\end{array}$ & $\begin{array}{c}\text { Not } \\
\text { Mexican } \\
\end{array}$ & All Wives \\
\hline \multicolumn{6}{|c|}{$\begin{array}{l}\text { Ethnicity is Mexican and Ancestry is } \\
\text { Mexican }\end{array}$} \\
\hline Row percent & 50.1 & 1.2 & 14.7 & 34.0 & $100.0 \%$ \\
\hline Avg. education of husbands & $\begin{array}{l}12.2 \\
(.02)\end{array}$ & $\begin{array}{l}12.1 \\
(.13)\end{array}$ & $\begin{array}{l}11.6 \\
(.05)\end{array}$ & $\begin{array}{l}13.3 \\
(.02)\end{array}$ & $\begin{array}{c}12.5 \\
(.02)\end{array}$ \\
\hline Avg. education of wives & $\begin{array}{l}12.2 \\
(.02)\end{array}$ & $\begin{array}{l}12.2 \\
(.14)\end{array}$ & $\begin{array}{l}10.4 \\
(.06)\end{array}$ & $\begin{array}{l}13.4 \\
(.02)\end{array}$ & $\begin{array}{l}12.4 \\
(.02)\end{array}$ \\
\hline \multicolumn{6}{|l|}{ General Hispanic } \\
\hline Row percent & 56.7 & 0.4 & 10.9 & 32.0 & $100.0 \%$ \\
\hline Avg. education of husbands & $\begin{array}{l}11.9 \\
(.06)\end{array}$ & $\begin{array}{l}11.0 \\
(.66)\end{array}$ & $\begin{array}{l}11.5 \\
(.15)\end{array}$ & $\begin{array}{l}13.0 \\
(.07)\end{array}$ & $\begin{array}{l}12.2 \\
(.04)\end{array}$ \\
\hline Avg. education of wives & $\begin{array}{l}12.0 \\
(.06)\end{array}$ & $\begin{array}{l}11.5 \\
(.77)\end{array}$ & $\begin{array}{l}10.5 \\
(.20)\end{array}$ & $\begin{array}{l}13.2 \\
(.07)\end{array}$ & $\begin{array}{l}12.2 \\
(.05)\end{array}$ \\
\hline \multicolumn{6}{|l|}{ Other ancestry } \\
\hline Row percent & 41.9 & 1.4 & 11.4 & 45.3 & $100.0 \%$ \\
\hline Avg. education of husbands & $\begin{array}{l}12.3 \\
(.10)\end{array}$ & $\begin{array}{l}12.7 \\
(.50)\end{array}$ & $\begin{array}{l}11.8 \\
(.26)\end{array}$ & $\begin{array}{l}13.2 \\
(.10)\end{array}$ & $\begin{array}{c}12.7 \\
(.07)\end{array}$ \\
\hline Avg. education of wives & $\begin{array}{l}12.3 \\
(.11)\end{array}$ & $\begin{array}{l}12.8 \\
(.34)\end{array}$ & $\begin{array}{l}10.4 \\
(.32)\end{array}$ & $\begin{array}{l}13.3 \\
(.09)\end{array}$ & $\begin{array}{l}12.5 \\
(.08)\end{array}$ \\
\hline \multicolumn{6}{|l|}{ Not reported } \\
\hline Row percent & 54.1 & 1.0 & 12.6 & 32.4 & $100.0 \%$ \\
\hline Avg. education of husbands & $\begin{array}{l}10.7 \\
(.11)\end{array}$ & $\begin{array}{l}10.8 \\
(.74)\end{array}$ & $\begin{array}{l}10.0 \\
(.26)\end{array}$ & $\begin{array}{l}12.4 \\
(.12)\end{array}$ & $\begin{array}{r}11.2 \\
(.08)\end{array}$ \\
\hline Avg. education of wives & $\begin{array}{l}10.9 \\
(.10)\end{array}$ & $\begin{array}{l}12.0 \\
(.54)\end{array}$ & $\begin{array}{l}8.9 \\
(.28)\end{array}$ & $\begin{array}{r}13.0 \\
(.09)\end{array}$ & $\begin{array}{l}11.3 \\
(.08)\end{array}$ \\
\hline \multicolumn{6}{|c|}{$\begin{array}{l}\text { Ancestry is Mexican and Ethnicity is } \\
\text { General or other Hispanic }\end{array}$} \\
\hline Row percent & 7.9 & 53.4 & 8.0 & 30.7 & $100.0 \%$ \\
\hline Avg. education of husbands & $\begin{array}{l}12.0 \\
(.16)\end{array}$ & $\begin{array}{l}11.6 \\
(.06)\end{array}$ & $\begin{array}{l}11.2 \\
(.18)\end{array}$ & $\begin{array}{l}12.6 \\
(.07)\end{array}$ & $\begin{array}{c}11.9 \\
(.04)\end{array}$ \\
\hline Avg. education of wives & $\begin{array}{l}12.0 \\
(.14)\end{array}$ & $\begin{array}{l}11.8 \\
(.05)\end{array}$ & $\begin{array}{l}9.7 \\
(.23)\end{array}$ & $\begin{array}{c}12.8 \\
(.06)\end{array}$ & $\begin{array}{c}12.0 \\
(.04)\end{array}$ \\
\hline \multicolumn{6}{|l|}{ Not Hispanic } \\
\hline Row percent & 5.5 & 8.6 & 3.0 & 82.9 & $100.0 \%$ \\
\hline Avg. education of husbands & $\begin{array}{l}12.7 \\
(.25)\end{array}$ & $\begin{array}{l}12.0 \\
(.26)\end{array}$ & $\begin{array}{l}11.4 \\
(.47)\end{array}$ & $\begin{array}{l}13.4 \\
(.06)\end{array}$ & $\begin{array}{l}13.2 \\
(.06)\end{array}$ \\
\hline Avg. education of wives & $\begin{array}{l}12.7 \\
(.30)\end{array}$ & $\begin{array}{l}11.9 \\
(.26)\end{array}$ & $\begin{array}{l}10.8 \\
(.53)\end{array}$ & $\begin{array}{l}13.6 \\
(.06)\end{array}$ & $\begin{array}{l}13.3 \\
(.06)\end{array}$ \\
\hline \multicolumn{6}{|l|}{ All U.S.-born Mexican husbands } \\
\hline Row percent & 45.1 & 6.4 & 13.1 & 35.4 & $100.0 \%$ \\
\hline Avg. education of husbands & $\begin{array}{l}12.1 \\
(.02)\end{array}$ & $\begin{array}{l}11.7 \\
(.05)\end{array}$ & $\begin{array}{l}11.5 \\
(.04)\end{array}$ & $\begin{array}{l}13.2 \\
(.02)\end{array}$ & $\begin{array}{c}12.4 \\
(.01)\end{array}$ \\
\hline Avg. education of wives & $\begin{array}{l}12.1 \\
(.02)\end{array}$ & $\begin{array}{l}11.9 \\
(.05)\end{array}$ & $\begin{array}{l}10.3 \\
(.05)\end{array}$ & $\begin{array}{l}13.4 \\
(.02)\end{array}$ & $\begin{array}{l}12.3 \\
(.01)\end{array}$ \\
\hline
\end{tabular}

Source: 2000 U.S. Census data.

Note: Standard errors are shown in parentheses. The sample includes husbands and wives in marriages that meet the following conditions: both spouses are between the ages of 25-59, the couple currently lives together, and the husband is U.S.-born and reports Mexican as an ethnicity and/or ancestry. Consequently, all of the husbands in these marriages are U.S.-born Mexicans, but their wives may be of any nativity and ethnicity. The sample includes 44,680 such marriages. 


\section{Table 5: The Extent and Selectivity of Intermarriage by U.S.-born Mexican Wives}

\begin{tabular}{|c|c|c|c|c|c|}
\hline \multirow[b]{2}{*}{ Wife’s Ethnicity/Ancestry } & \multicolumn{5}{|c|}{ Nativity and Mexican Ethnicity/Ancestry of Husband } \\
\hline & $\begin{array}{l}\text { U.S.-born of } \\
\text { Mexican } \\
\text { Ethnicity }\end{array}$ & $\begin{array}{l}\text { U.S.-born of } \\
\text { Mexican } \\
\text { Ancestry }\end{array}$ & $\begin{array}{c}\text { Foreign-born } \\
\text { Mexican } \\
\end{array}$ & $\begin{array}{c}\text { Not } \\
\text { Mexican } \\
\end{array}$ & All Husbands \\
\hline \multicolumn{6}{|c|}{$\begin{array}{l}\text { Ethnicity is Mexican and Ancestry is } \\
\text { Mexican }\end{array}$} \\
\hline Row percent & 45.2 & 1.0 & 18.9 & 35.0 & $100.0 \%$ \\
\hline Avg. education of husbands & $\begin{array}{l}12.2 \\
(.02)\end{array}$ & $\begin{array}{l}12.3 \\
(.14)\end{array}$ & $\begin{array}{l}9.7 \\
(.05)\end{array}$ & $\begin{array}{l}13.7 \\
(.02)\end{array}$ & $\begin{array}{c}12.3 \\
(.02)\end{array}$ \\
\hline Avg. education of wives & $\begin{array}{l}12.2 \\
(.02)\end{array}$ & $\begin{array}{l}12.2 \\
(.13)\end{array}$ & $\begin{array}{l}11.5 \\
(.04)\end{array}$ & $\begin{array}{l}13.3 \\
(.02)\end{array}$ & $\begin{array}{l}12.5 \\
(.01)\end{array}$ \\
\hline \multicolumn{6}{|l|}{ General Hispanic } \\
\hline Row percent & 46.9 & 0.6 & 14.4 & 38.1 & $100.0 \%$ \\
\hline Avg. education of husbands & $\begin{array}{l}12.0 \\
(.06)\end{array}$ & $\begin{array}{l}12.4 \\
(.43)\end{array}$ & $\begin{array}{l}9.5 \\
(.16)\end{array}$ & $\begin{array}{l}13.3 \\
(.05)\end{array}$ & $\begin{array}{c}12.1 \\
(.04)\end{array}$ \\
\hline Avg. education of wives & $\begin{array}{l}12.0 \\
(.05)\end{array}$ & $\begin{array}{l}11.7 \\
(.65)\end{array}$ & $\begin{array}{l}11.3 \\
(.11)\end{array}$ & $\begin{array}{l}13.0 \\
(.05)\end{array}$ & $\begin{array}{l}12.3 \\
(.04)\end{array}$ \\
\hline \multicolumn{6}{|l|}{ Other ancestry } \\
\hline Row percent & 34.7 & 1.8 & 16.6 & 46.9 & $100.0 \%$ \\
\hline Avg. education of husbands & $\begin{array}{l}12.3 \\
(.09)\end{array}$ & $\begin{array}{l}12.3 \\
(.47)\end{array}$ & $\begin{array}{l}9.4 \\
(.23)\end{array}$ & $\begin{array}{l}13.3 \\
(.09)\end{array}$ & $\begin{array}{c}12.3 \\
(.07)\end{array}$ \\
\hline Avg. education of wives & $\begin{array}{l}12.3 \\
(.10)\end{array}$ & $\begin{array}{l}12.3 \\
(.56)\end{array}$ & $\begin{array}{l}10.9 \\
(.18)\end{array}$ & $\begin{array}{l}13.3 \\
(.08)\end{array}$ & $\begin{array}{c}12.5 \\
(.06)\end{array}$ \\
\hline \multicolumn{6}{|l|}{ Not reported } \\
\hline Row percent & 50.6 & 1.1 & 12.1 & 36.2 & $100.0 \%$ \\
\hline Avg. education of husbands & $\begin{array}{l}11.0 \\
(.10)\end{array}$ & $\begin{array}{l}10.5 \\
(.76)\end{array}$ & $\begin{array}{l}8.4 \\
(.25)\end{array}$ & $\begin{array}{l}13.1 \\
(.08)\end{array}$ & $\begin{array}{c}11.4 \\
(.07)\end{array}$ \\
\hline Avg. education of wives & $\begin{array}{l}10.8 \\
(.09)\end{array}$ & $\begin{array}{l}10.8 \\
(.73)\end{array}$ & $\begin{array}{l}10.3 \\
(.19)\end{array}$ & $\begin{array}{l}12.2 \\
(.10)\end{array}$ & $\begin{array}{l}11.2 \\
(.07)\end{array}$ \\
\hline \multicolumn{6}{|c|}{$\begin{array}{l}\text { Ancestry is Mexican and Ethnicity is } \\
\text { General or other Hispanic }\end{array}$} \\
\hline Row percent & 7.8 & 49.7 & 15.0 & 27.6 & $100.0 \%$ \\
\hline Avg. education of husbands & $\begin{array}{l}12.0 \\
(.14)\end{array}$ & $\begin{aligned} 11.6 \\
(.06)\end{aligned}$ & $\begin{array}{l}8.7 \\
(.17)\end{array}$ & $\begin{aligned} 13.1 \\
(.07)\end{aligned}$ & $\begin{array}{l}11.6 \\
(.05)\end{array}$ \\
\hline Avg. education of wives & $\begin{array}{c}12.2 \\
(.14)\end{array}$ & $\begin{array}{c}11.8 \\
(.05)\end{array}$ & $\begin{array}{c}11.2 \\
(.11)\end{array}$ & $\begin{array}{c}12.9 \\
(.06)\end{array}$ & $\begin{array}{c}12.0 \\
(.04)\end{array}$ \\
\hline \multicolumn{6}{|l|}{ Not Hispanic } \\
\hline Row percent & 5.7 & 7.7 & 4.5 & 82.1 & $100.0 \%$ \\
\hline Avg. education of husbands & $\begin{array}{l}12.2 \\
(.28)\end{array}$ & $\begin{aligned} 12.1 \\
(.24)\end{aligned}$ & $\begin{array}{l}9.8 \\
(.56)\end{array}$ & $\begin{aligned} & 13.6 \\
&(.06)\end{aligned}$ & $\begin{array}{l}13.2 \\
(.06)\end{array}$ \\
\hline Avg. education of wives & $\begin{array}{l}12.3 \\
(.27)\end{array}$ & $\begin{array}{l}11.8 \\
(.28)\end{array}$ & $\begin{array}{l}11.6 \\
(.41)\end{array}$ & $\begin{array}{l}13.2 \\
(.05)\end{array}$ & $\begin{array}{l}13.0 \\
(.06)\end{array}$ \\
\hline \multicolumn{6}{|l|}{ All U.S.-born Mexican wives } \\
\hline Row percent & 40.5 & 5.7 & 17.2 & 36.6 & $100.0 \%$ \\
\hline Avg. education of husbands & $\begin{array}{l}12.1 \\
(.02)\end{array}$ & $\begin{array}{l}11.7 \\
(.05)\end{array}$ & $\begin{array}{l}9.5 \\
(.05)\end{array}$ & $\begin{array}{l}13.6 \\
(.02)\end{array}$ & $\begin{array}{r}12.2 \\
(.01)\end{array}$ \\
\hline Avg. education of wives & $\begin{array}{l}12.1 \\
(.02)\end{array}$ & $\begin{aligned} 11.9 \\
(.05)\end{aligned}$ & $\begin{aligned} 11.4 \\
(.03)\end{aligned}$ & $\begin{array}{c}13.2 \\
(.02)\end{array}$ & $\begin{array}{l}12.4 \\
(.01)\end{array}$ \\
\hline
\end{tabular}

Source: 2000 U.S. Census data.

Note: Standard errors are shown in parentheses. The sample includes husbands and wives in marriages that meet the following conditions: both spouses are between the ages of 25-59, the couple currently lives together, and the wife is U.S.-born and reports Mexican as an ethnicity and/or ancestry. Consequently, all of the wives in these marriages are U.S.-born Mexicans, but their husbands may be of any nativity and ethnicity. The sample includes 49,726 such marriages. 


\section{Table 6: Intermarriage and Mexican Identification of Children}

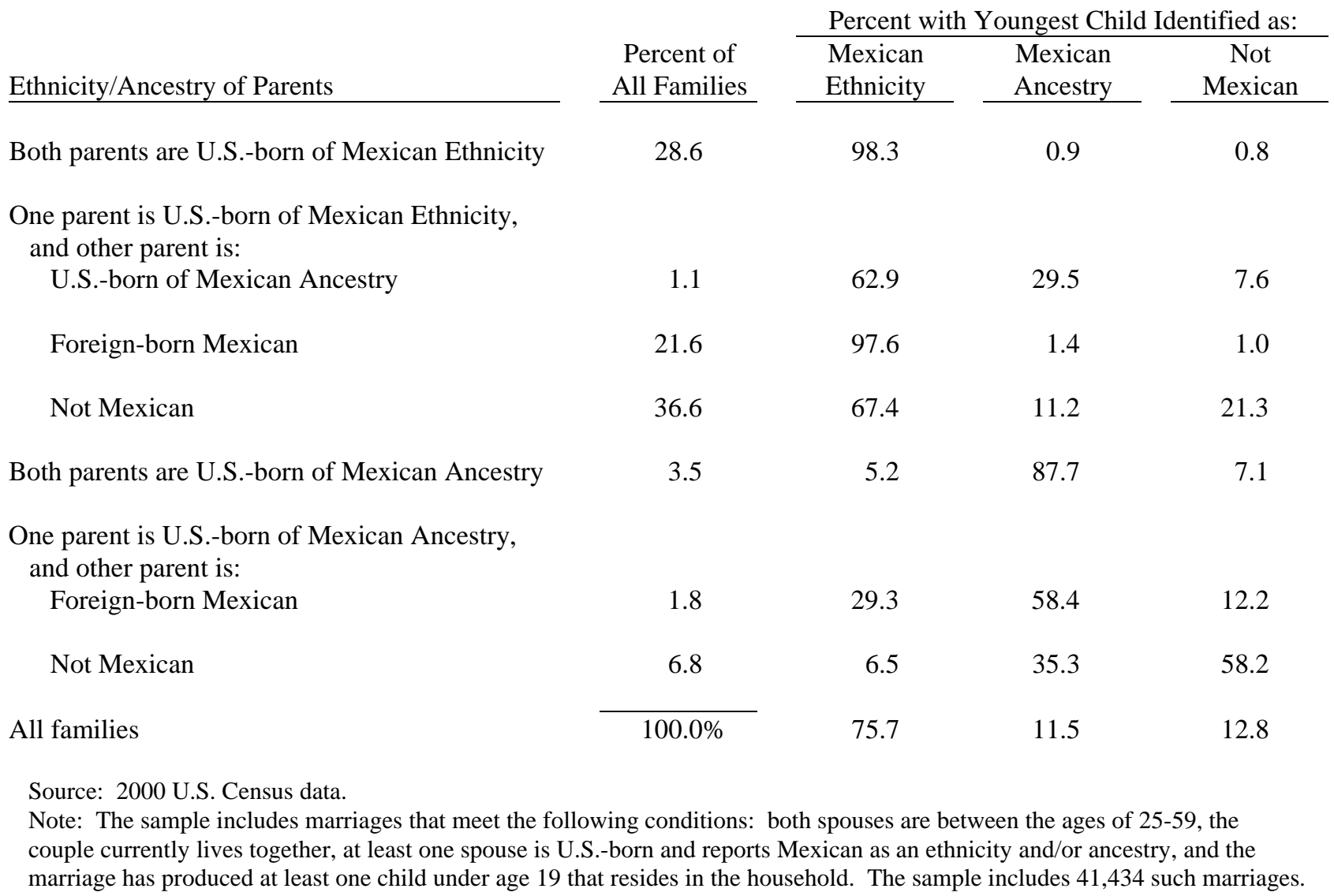




\section{Table 7: Parental Human Capital by Mexican Identification of Youngest Child}

\begin{tabular}{|c|c|c|c|c|}
\hline & \multicolumn{3}{|c|}{ Youngest Child Identified as: } & \multirow[b]{2}{*}{$\begin{array}{c}\text { All } \\
\text { Families }\end{array}$} \\
\hline & $\begin{array}{l}\text { Mexican } \\
\text { Ethnicity }\end{array}$ & $\begin{array}{l}\text { Mexican } \\
\text { Ancestry }\end{array}$ & $\begin{array}{c}\text { Not } \\
\text { Mexican }\end{array}$ & \\
\hline \multicolumn{5}{|l|}{ Fathers } \\
\hline Avg. years of education & $\begin{array}{l}12.1 \\
(.02)\end{array}$ & $\begin{array}{l}12.5 \\
(.04)\end{array}$ & $\begin{array}{l}13.2 \\
(.03)\end{array}$ & $\begin{array}{l}12.3 \\
(.01)\end{array}$ \\
\hline Percent with deficient English & $\begin{array}{l}18.1 \\
(.22)\end{array}$ & $\begin{array}{l}12.9 \\
(.49)\end{array}$ & $\begin{array}{l}5.6 \\
(.32)\end{array}$ & $\begin{array}{l}15.9 \\
(.18)\end{array}$ \\
\hline \multicolumn{5}{|l|}{ Mothers } \\
\hline Avg. years of education & $\begin{array}{l}12.3 \\
(.02)\end{array}$ & $\begin{array}{l}12.7 \\
(.04)\end{array}$ & $\begin{array}{l}13.1 \\
(.03)\end{array}$ & $\begin{array}{l}12.5 \\
(.01)\end{array}$ \\
\hline Percent with deficient English & $\begin{array}{l}15.9 \\
(.21)\end{array}$ & $\begin{array}{l}11.8 \\
(.47)\end{array}$ & $\begin{array}{l}5.6 \\
(.32)\end{array}$ & $\begin{array}{l}14.1 \\
(.17)\end{array}$ \\
\hline
\end{tabular}

Source: 2000 U.S. Census data.

Note: Standard errors are shown in parentheses. The sample includes marriages that meet the following conditions: both spouses are between the ages of 25-59, the couple currently lives together, at least one spouse is U.S.-born and reports Mexican as an ethnicity and/or ancestry, and the marriage has produced at least one child under age 19 that resides in the household. The sample includes 41,434 such marriages. 